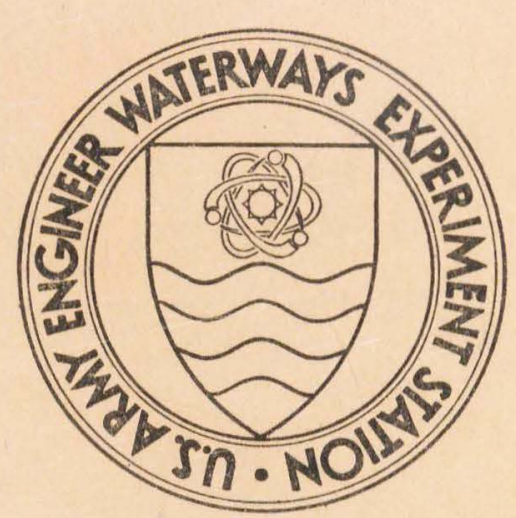

MISCELLANEOUS PAPER M-7I-3

\title{
THE PERFORMANCE OF TWO BOEING-GM WHEELS (GM VII AND GM VIII) FOR THE MANNED LUNAR ROVER VEHICLE
} by

A. J. Green, K.-J. Melzer
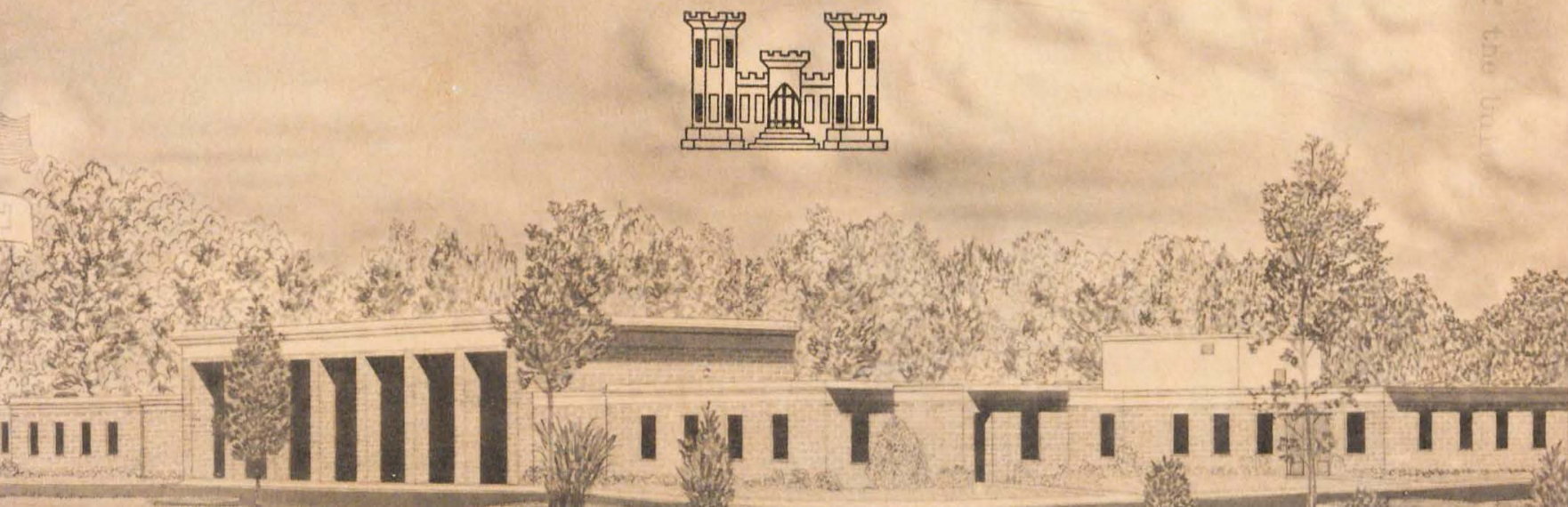

WeSEAWCH CERIER LBRARY

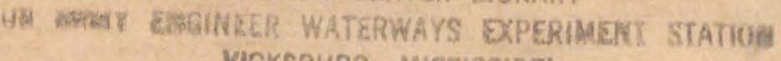

YICKSBURG. MISSISSIPPI

February 1971

Sponsored by George C. Marshall Space Flight Center

National Aeronautics and Space Administration, Huntsville, Alabama

Conducted by U. S. Army Engineer Waterways Experiment Station, Vicksburg, Mississippi 
Destroy this report when no longer needed. Do not return it to the originator.

The findings in this report are not to be construed as an official

Department of the Army position unless so designated by other authorized documents. 


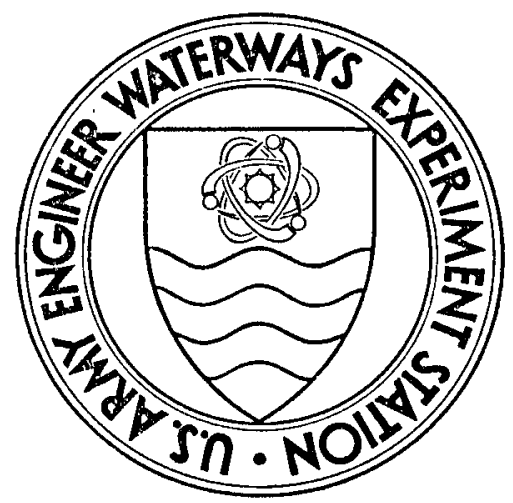

MISCELLANEOUS PAPER M-7I-3

\section{THE PERFORMANCE OF TWO BOEING-GM WHEELS (GM VII AND GM VIII) FOR THE MANNED LUNAR ROVER VEHICLE}

by

A. J. Green, K.-J. Melzer

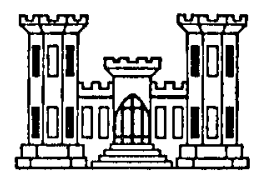

February 1971

Sponsored by George C. Marshall Space Flight Center

National Aeronautics and Space Administration, Huntsville, Alabama

Conducted by U. S. Army Engineer Waterways Experiment Station, Vicksburg, Mississippi 
(.) $3: 1$

No.pra $:-3$

$\cos 0.2$

THE CONTENTS OF THIS REPORT ARE NOT TO BE USED FOR ADVERTISING, PUBLICATION, OR PROMOTIONAL PURPOSES. CITATION OF TRADE NAMES DOES NOT CONSTIIUTE AN OFFICIAI ENDORSEMENT OR APPROVAL OF THE USE OF SUCH COMMERCIAL PRODUCTS. 
The stucly reported herein was conducted by personnel of the Mobility Research Branch (MRB), Mobility and Environmental (M\&E) Division, U. S. Army Engineer Waterways Experiment Station (WES). The study was sponsored by the Lunar Exploration office, National Aeronautics and Space Administration, Washington, D. C., and it was under the technical cognizance of Dr. N. C. Costes of the Space Sciences Laboratory, George C. Marsha11 Space Flight Center (MSFC), Huntsvil1e, Ala. The work was performed under N $\Lambda \mathrm{S} \Lambda$ - Defense Purchase Requcst No. H-65056A, dated 16 December 1969.

The tests were conducted under the general supervision of Messrs. W. G. Shockley and S. J. Knight, Chief and Assistant Chief, respectively, of the M\&E Division; and under the direct supervision of Mr. A. J. Green and Dr. K.-J. Mclzer of the Research Projects Group, MRB. This report was prepared by Mr. Green and Dr. Melzer.

The wheels used in this study were furnished by the A. C. Electronics Division of General Motors Corporation in cooperation with the Boeing Company (Huntsville, Ala.) and MSFC.

Acknowledgment is made to Dr. D. R. Freitag, Assistant Technical. Director, WES, for his advice and assistance during this study.

COI Levi A. Brown, CF, and COI, Ernest D. Peixotto, CE, were Directors of Wles during the conduct of this study and preparation of this report.

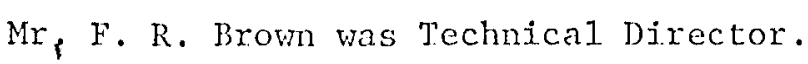


FOREWORD . . . . . . . . . . . . . . . . . . . . . v v

NOTATION . . . . . . . . . . . . . . . . . . . . IX

SUMMARY . . . . . . . . . . . . . . . . . . . xiij.

PART' I: INIRODUCTTON . . . . . . . . . . . . . . . . . . . . 1

Background . . . . . . . . . . . . . . . . . . 1

Purpose and Scope. . . . . . . . . . . . . . . . 2

PART II: TEST PROGRAM . . . . . . . . . . . . . . . . 3

Soil . . . . . . . . . . . . . . . . . . 3

Test Equipment . . . . . . . . . . . . . . . . . . . . 4

Test Procedures and Intexpretation of Data . . . . . . . . 4

PART III: PRESENTATION AND ANALYSIS OF RESUITS . . . . . . . . 6

Soil Tests . . . . . . . . . . . . . . . . 6

Performance of the Fabric-Covered Whee1 (GM VIT) . . . . . . 6

Performance of the Open-Wire-Mesh Whee1 (GM VIII) . . . . . . 8

Comparative Performance of Covered and Open Wheels . . . . . 10

PART IV: CONCLUSIONS . . . . . . . . . . . . . . . . 12 TABLJS $1-4$

EIGURES 1-28 


\section{BOTATOON}

(Reproduced from WES Technical Report $\mathbf{H}-70-2$, "Per:formance of theels for Iunar Vehicles." Many symbols shown are not used in this report.)

$\Lambda$ : Sheas: area, $\mathrm{cm}^{2}\left(\mathrm{in} .^{2}\right)$

A Hard-surface contact area, $\operatorname{cm}^{2}\left(\mathrm{in},{ }^{2}\right)$

$A_{g}$ Active grousex area, $\mathrm{cm}^{2}\left(\mathrm{in}^{2}{ }^{2}\right.$ )

$b$ Width of when; width of grouser, cin (in.).

c Cobeston of tire soi.1, $\mathrm{kiv} / \mathrm{m}^{2}$ (psi.)

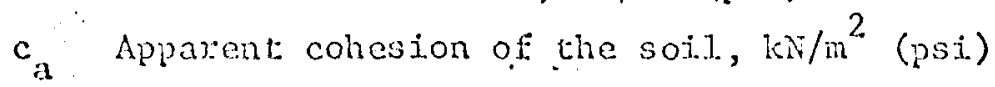

$c_{b}$ Cohesion detemined from bevameter tests, $k \mathrm{k} / \mathrm{m}^{2}$ (psi) 1 .

$c_{c}$ Cohesion delermined from sheargraph tests, $\mathrm{kN} / \mathrm{m}^{2}$ (psi.)

$c_{p}$. Cohesion determined from plate in situ sheax tests, $\mathrm{kN} / \mathrm{m} 2$ (psi)

$c_{t}$. Cohesion corresponding to tangent friction angle, $\mathrm{kN} / \mathrm{m}^{2}$ (psi)

$c_{\text {tr. }}$ Cohesion determined from trenching tests, $\mathrm{kN} / \mathrm{m}^{2}$ (psi)

$\mathrm{Ca}$. Force due to apparent cohesion of the soil, $\mathrm{N}$ (1.b)

$\mathrm{C}_{\mathrm{u}}$ Coefficient of uniformity of the soj.l $=\mathrm{d}_{60} / \mathrm{d}_{10}$

d Theel diameter, cm (in.)

$\mathrm{d}_{\mathrm{m}}$ : Kean diameter of soij. grains, $\mathrm{mm}$ (in.)

${ }_{60}$ Grainmize diameter at 60 percent finex by veight, min. (in.)

D Depth, cm (in.)

$D^{\prime} \because$ Compactability, $\%=100\left(\frac{c_{\text {nax }}-c_{\min }}{c_{\text {min }}}\right)$

$D_{x}$ Relative density, $\%=100\left(\frac{e_{\max }-e}{e_{\max }-e_{\min }}\right)$

e Initial void ratio

e $_{\max }$ Maximum vold ratio

enin Minimum void ratio

F Friction force, $N(1 \mathrm{~b})$

G. Penetration resistance gradient, $\mathrm{MN} / \mathrm{m}^{3}$ (pci*)

$k_{c}, k_{\phi}, n$ Bekker: soil values

$\mathrm{k}_{\mathrm{d}}$ Count ratio (wet density)

$\therefore k_{m}$ Comt ratio (moisture content)

$M$ Torque, $m-N(f t-1 b)$.

$\mathrm{N}_{\mathrm{g}}$. Number of grousera embedied in sol.1

$\stackrel{P}{P}$ puil, N (Ib) 
PN Rower number, $\mathrm{M} / \mathrm{Tr} \mathrm{e}^{(\mathrm{l}-\mathrm{s})}$

$\mathrm{q}_{\mathrm{c}}$, Cone penctration resistance, $\mathrm{kN} / \mathrm{in}^{2}$ (psi.)

$r$ Radius of shear head, $\mathrm{cm}$ (in.)

$x_{e}$ Effective wheel radius, in (in.)

$R$ Iength of torque arm, cm (in.)

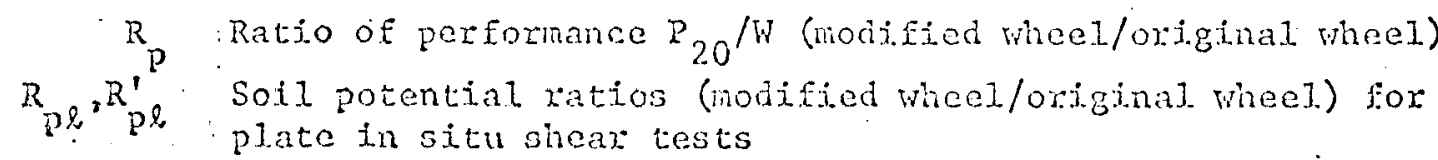
$R_{t}, R_{t}^{\prime}$. Soil potential ratios (modified wheel/original wheel) for

3 Slip, \%

${ }^{3} \mathrm{~A}$ Average settlement of the plate in the in situ shear tests

$s_{b}$. Shear: stress determined from bevaneter tests, $\mathrm{kN} / \mathrm{m}^{2}$ (psi)

${ }_{\mathrm{s}}$. Shear stress determined from sheargraph tests, $\mathrm{kN} / \mathrm{m}^{2}$ (psi)

${ }^{\mathrm{s}} \mathrm{v}$. Shear stress detcrmined from vane shear tests, $\mathrm{kN} / \mathrm{m}^{2}$ (psi.)

$\mathrm{S}$ : Soil potential

$\mathrm{s}_{\mathrm{pl}}{ } \mathrm{s}_{\mathrm{pl}}$, Soj.l potential. (plate in situ shear tests)

$\mathrm{S}_{\mathrm{t}}, \mathrm{S}_{\mathrm{t}}^{\prime}$ Soil potential (vacuum triaxial tests)

$v$ ". Translational speed of a vheel, $\mathrm{m} / \mathrm{sec}$ (fps)

V. Volume

v Molsture content, \% (percent of dry density)

$w^{\prime}$ Moisture content, $\mathrm{g} / \mathrm{cm}^{3}$ (pcf) (nass per volume)

$\mathrm{W}$ Load; veight, if (lb)

z Grouser height, cm (in.)

a Sjope angle, deg

$\gamma$ Wet density, $\mathrm{g} / \mathrm{cm}^{3}$ (pci)

$\gamma_{d}$ Dry density, $g / \mathrm{cm}^{3}$ (pci)

$\gamma_{s}$ Specific gravity

$\Delta$ \% Horizontal displacenent of the plate in the In situ shear tests

$\Delta V / V$ Volume change, $\%$

E $\quad$ xxial strain, \%

$\eta^{\prime}$ Effictency a ratio of recoverable energy to total energy input

$\lambda_{p}$ Passive earth pressure factor for Rankine case

o stresg, $\mathrm{kN} / \mathrm{m}^{2}$ (po1)

$\sigma_{1}$ Major principal stress, $\mathrm{kN} / \mathrm{m}^{2}$ (psi)

$\sigma_{2}, \sigma_{3}$ Minor principal. stresses, $\mathrm{kN} / \mathrm{m}^{2}$ (psi)

$\sigma_{\mathrm{n}}$ Normal otresa, $\mathrm{kN} / \mathrm{m}^{2}$ (psi) 
T Shear stoess, $\mathrm{kid} / \mathrm{m}^{2}$ (psi)

${ }^{r} \mathrm{v}$ : Energy component of tocal shear scress

$\$$, Friction angle, deg

$\phi_{b}$. Fricion angle determined from beyameter cests, cieg

${ }_{\mathrm{c}}$. Friction angle detexmined from sheargraph tests, deg

$\phi_{\mathrm{d}}$. Friction angle detemined from dixect shear tests, deg

${ }_{\text {P }}$... Peak friction angle detemined from plane strain tests, deg

Spe. Friction angle detemined from place in situ shear tests, deg

${ }_{r}$ True froction angle, deg

$\gamma_{\beta}$ Secant friction angle determined from triaxial tests, deg

$\phi_{t}$. Tangent friction angle determined from triaxial tests, deg

() Rotational velocity of the theel, ipm 


\section{SUMMARY}

I'wo candidate wheels for the Boeing-GM Manned Lunar Rover Vehicle, one fabric-covered and one constructed of open-wire mesh, vere tested for mobility persornance in a fine sand. Four levels of sund strength, representing cohesion values ranging from zero to $0.16 \mathrm{psi}$, were used. in the tests. 'he cohesional and frictional properties of the sand spanned a range that is believed to include the probable range of lunar soil properties.

A dynamometer system was used to conduct programned-slip tests with the vireels. The slip was varied from a negative slip of $15 \%$ to a posjtive slip of $100 \%$. The wheels were tested at the average design load $(59 \mathrm{lb})$ and at 75 and $3.25 \%$ of that load, so the influence or loud imbalance and dynemic load transfer could be assessed. The average speed at 0 percent slip was $3 \mathrm{ft} / \mathrm{sec}$.

The test results show that the covered whecl was able to achieve the desirea tractive performance (pull/veight ratio $=0.47$, equivalent to climbing a 25 -deg slope) in the two strongest soil conditions, but not in the two veakest ones. The open wheel was not able to achieve this tractive performance in any of the soil conclitions tested. In the sarne soil condition, the naximum pull/veight ratio for the open wheel wes consistently less than that for the covered wheel.

The power required to attain a given level of tractive performance (below the maximum for a given wheel) was about the same for both wheels in all soil conditions. The power requirenent was greater on the waker soils than on the stronger, and it increased alnost linearly with increasing puld/veight ratio. On level soil, cach wheel required about 7 whr/wa at the nominal rated load of $59 \mathrm{lb}$.

There was no consistent difference in the dinensionless perform ance ratios (pull/wejght, power number, efficiency) as a direct result of any of the three loods used. Thus, the effects of moderate load inbilances do not appear critical.

The soil condition dosignated $\mathrm{C}_{O}$ was easily compacted by passage of the vheel. The results of one test vith each wheel in this soil condition showed that the covered wheel compacted the soil. to a denser state than the open wheel dia. 
THE PERFOPMANCE OF TWO BOEING-GM WHEEIS (GI VII AHD GH VIII)

FOR THE MANIED LUNAR ROVER VEHTCLE

\section{PART I: INTRODUCTIOH}

\section{Background}

1. Tests conducted in the summer of 1969 by the U. S. Army Engineer Waterways Experiment station (WES) to quantify the performance of the 10-in.dian Bendix, Boeing-Gll, and Grumnan wheels indicated that the latter two wheels (as delivered to UES) did not meet the requirements for slope-clinbing ability, i.e. 25 deg on sandy soil. Accordingly, during the course of that test program, simple modifications of these two wheels vere made in an attempt to improve thein performance. In the case of the Boeing-Cr wheol, it was domonstrated that both reducing the stiffness of the whed and adding a fabric cover to it improved its penfornance. These tests are fully reported in WES Technical Report No. M-70-2.:

2. After the contract for the Kenned Junar Roven Vohicle (liLRV) system was awarded to The Bosing Conpany, its subcontractor, Goneral lotors Corponation, fabricated two new $40-i n$-dian whecls, one with inner and outer wire-mesh surfeces soparated by a layer of fabric and with traction spikes attached to the outer sumface, and the other of open wire nesh and with cheven netal treads (see fig. 2 ). At the

Hreitag, D. R., Groen, $\Lambda$. J, and Kelaen, K.-J., "Performance Evaluation of Wheols for luner Vohicles," Techical Report No. $\because-70-2$, Varch 1970 , U. S. Amy Fidineor Vaterwas Froniment station, Cl: vicksburg, Mississipi. 
request of the George C. Mershall space Flight Center (MSFC), WES conducted tests to evaluate the performance of these two whesls. The results are reported herein.

\section{Purpose and Scope}

3. The purpose of this test program was to deternine the quantitative performance of the fabric-covered whed (GN VII) and the open-wire-mesh wheel (Gll VIII). The test program consisted of a series of single-wheed programmed-sljp tests in the same sand used in the earljer tests*. As had been clone in these earlier tests, the consistency of the sand was varied to cover a range of conesicnu? and frictional properties to simulate soil conclitions assumed to exist on the moon. Four soil conclitions, $\mathrm{S}_{1}, \mathrm{C}_{0}, \mathrm{C}^{\prime}{ }_{2}$, and $\mathrm{C}_{2}$ (see table 1), were used in the test progran. Initially, tests were to be conducted on each soil condition at $50,75,100,125$, and $150 \%$ of the design load of 55-60 lb. Hoveven, by mutual agrement, testing at 50 and $150 \%$ of the design loads was defenred. The same soil, wheel, and wheel-performance parameters neasured in earlier tests vere measured in this test program.

:Ibid., p 1. 


\section{Soil}

Description

4. The soil used in this study was a fine dune sand from the desert near Yuma, Arizona. It was classified SF-SM according to the Unified Soil Classification system. Gradation and classification data, together with density and void ratio values, are given in fig. 2. This soil is primarily cohesionless, but it exhibits a snall amount of: cohesion, particularly when damp.

Preparation

5. Level surfaces. The desired soil condition in dry sand was obtained in the following manner: The test birs were filled and the soil was plowed with a seed fork to a depth of $12 \mathrm{in.}$. For loose conditions, no compaction effort was necessary, so the surface of: the plowed section was screeded level; for the denser conditions, compaction was applied at the surface with a vibuator before screeding. The relation between dry density and relative density for the material. is shown in fig. 3 .

6. To prepare the wet sond, a batch of ciry sand was spread on the floor, water was adcled, and the naterial was thoroughly nived until the desired noisture content wis reached. The naterial was tien dumped into the bins for further processing (i.e. compacting and leveling), which was the sane as for the dry sand. The moisture level in these sections was held constant by covering them when not in use and occasionally 
spraying the surface very lightly with water to cornpensate for evaporation. The wet soil was reprocessed in place, being removed from the soil bins only when a different level of moisture was required. During the testing cycles in this test program, the unifornity of soil conditions was cnsured by frequent determination of noisture content and density and by measurements with the cone penetroneter.

\section{Test Equipment}

7. The dynamometer system used in these tests can accomadate loads from approximately 15 to slightly more than 200 lh, and wheels ranging from $18 \mathrm{in.}$ to $45 \mathrm{in}$, in diameter. Vertical load, horizontal force (drawbar pull), torque, sinkage, carriagc speed, and wheel speed were continuously measured during each test by instrumentation on the dynamometer campiage. The average translational wheel speed at 0 percent slip was approximately $3 \mathrm{ft} / \mathrm{sec}$; the rotational speed was constant.

\section{Test Procedures and Interpretation of Data}

8. A programed-sidp techique vas used in all the single-wheol tests. The test was started when the whed was in the regative slip range, i.e. the translational speed of the carriage was greater than that of the wheel. The carriage was slowed at a prorramed, unifom rate (wheel speed was approxinately constant) to cause the whel. to pass through the zero-torque point, the $0 \%$ silp point, the self-propelied point, etc., as slip progressively increased to $100 \%$. 
9. The relation of pull anc torque to slip can be show by two curves, such as those in fig. 4 that represent data obtand with the open-mesh wheel (GM VIII). Pull and torque increased at a decreasing rate and often reached a plateau after a slip of about $20 \%$ had been achieved. Although all tests were not identical, pull and torque in noarly all of them hac reached a plateal, on significantly loner rate of increase, at a slip of $20 \%$, so data for comparing perfomance of: the two wheols were read at $20 \%$ slip.

10. The general shape of the efficiency vorsus slip curve for the GM VIII wheel is show in fig. 5. This relation was generally similar to that for the GU VII wheel. However, in some instances, a peak efficiency point was difficult to determine. For consistency and ease of comparison, efficiency at $20 \%$ slip was recorded for all the tests.

11. The plot of the power number PN $\left[M / W_{e}(1-s)\right]$ versus the pull coefficient $P / V($ sec $f i g .6)$ is especially impontant, since it expresses the energy consumed per unit of distance per unit of wheel or vohicle weight in relation to drawbar pull/slope-clinbing ability. pis at 0 pull; PN on a 15-deg slope (PNi.5), PN on a 25 -deg slope (PH, 25 ), and Pll at the point on the curve where pis ascends alnost vertically (PN max') were recorded. To obtain whr/kn conforring to a slope of 15 deg, read the value of $\mathrm{PII} 15$ or $\mathrm{P} / \mathrm{W}=0.27\left(\tan 25^{\circ}=0.27\right)$, and multiply this value by the desired meel loac or vehicle weight in vowtons anc the fraction $1000 / 3600$. 


\section{PART III: PRESENTATIOI AND ANALYSIS OF RESULTS}

\section{Soil. Tests}

12. The soil tests conducted in this program included cone and plate penetration resistance, moisture content, density, plate in-situ shear vith a rough-surfaced rectangular plate, and plate in-situ shear data collected previously. $*$

13. Values of the following parameters pertinent to the tests reported herein are contained in table 1: penotration resistance gradient, $G$; bevameter values, $k_{c}, k_{\phi}, n, \phi_{b}$, and $c_{b}$; cohesion from trenching tests, $c_{t r}$; tangent friction anglo from triasial tests, $\phi_{t}$; friction angle from plate in-situ shear tesi, $\phi_{p_{l}}$; density, $\gamma$, relative density, ${ }_{n}$; and noisture content, $w$.

\section{Performance of the Fabric-Covered Vheel (Gll VII)}

\section{Pull and torque}

14. The relations of the puld and torque coefficients to silp on soil prepared to four differont consistencies are shown in figs. $7-10$. The following observations can be made:

a. The rate of increase in pull and torque coefficients with slip in the $0.20 \%$ sip range generally increased vith soil. strength, anc the pojnt at which the slape of the torquemsip and puld-slip relations chenged rapicly was reached at a lower slip in the stronger matenials.

IIbid. : $p 2$. 
For cxample, this point was reached at about $15 \%$ sliy on the $\mathrm{C}_{2}$ soil condition $(G=12.0 \mathrm{psi} / \mathrm{in}$.$) , and at slightly$ Ereater than $20 \%$ slip on the $\mathrm{S}_{1}$ soil condition $\left(G=2.0 \mathrm{psi} / \mathrm{jn}_{\mathrm{n}}\right)$.

b. There was no elear-cut tendency for the wheel. to perform better at the design load than at the other loads (75 and $125 \%$ or design load).

c. The pull-slip curves did not display the vell-aldined plateaus that were noted for the 40-in.-dian whecls tested in the carliex program.* Instead, they showed a gradual increase in pull coefficient vith slip in the 20 80\% range. Power number versus puli coefficient/slope-climbing ability

15. Plots of power number versus puld coefficicnt/slope angle for the test loaks on each of the four soil conditions are shom in figs. 11-24. The following observations can be made:

a. Power number increased directly with pull coefficient (or slope angle) to a maximum, or near maximum, value of the latter dual paranster and then rose almost vertically.

b. No significant or consigtent effect of load per se was 1 cvident.

c. The power number between zero and the naximun pull coefficient (or: slope angle) generally was higher for the two lower soil strengthe $\left(c_{0}, s_{1}\right)$ than for the two higher strengths $\left(\mathrm{C}_{1}, \mathrm{C}_{2}\right)$.

16. The curves in figs. $13-14$ can be used to compute the power : Ibj.,, $\mathrm{p}$. 
consumption rate on level and sloping surfaces by the formula

$$
\begin{aligned}
& \text { Power consumption rate }=\text { PI } \times \frac{1000}{3600} \times 1 \text { oad (Ii) } \\
& \text { in units of whr } / \mathrm{km} / \mathrm{whecl}
\end{aligned}
$$

For exanple, from fig. 11, the power number for a 59-1b (260-15) 1oad on a 15 -deg slope is read to be 0.46 . Thus the pover consumption rate (per wheel) is

$$
0.46 \times \frac{1000}{3600} \times 260=33.3 \mathrm{whr} / \mathrm{km} / \text { wheel }
$$

\section{Efficiency}

17. Whe relative efriciency of the vheel is shom in table 2. In terms of the ratio of output work to input work at the $20 \%$ sitp point, efficiency is expressed:

$$
\eta^{\prime}{ }_{20}=\frac{P / W}{M / W r_{e}} \quad(1-s)=\frac{P r_{e}}{M}(1-s)=\frac{P r e}{M} \cdot 0.8
$$

It is noted that $n^{\prime}$ does not vary noticedbly with load, but does show an increase as soil strength increases. Flhis trend supports the reasoning that nore work is dissipated in deforming the veaker soilss.

\section{Sinkage}

18. In general, sinkages vere smald. The groatest sinkage occurred during tests in the $\mathrm{C}_{0}$ soil condition. The relation of sintage to slip for a 59-.2b load in the $C_{0}$ soil condition is shown in fig. 15.

\section{Performance of the Open-Wire-mitesh Whed (GM VITI)}

Pull and torque

19. The relations of the pul.3. and torque coefficients to slip for: the GI VII wheed tested on soi] prepared at the sane consistencies as those for the tests with the fabric-covered whel are shom in fiEs. 16..19. The following observetions, generelly parajel to those 
Given for the fabric-covered wheel, are made:

a. The rate of increase in torque coefficient with s]ip, in the $0-20 \%$ slip range, tended to increase vith soil strength, and the point at which the slope of the torqueslip relation changed rapidiy was reached at a lower slip on the stronger soils.

b. Again, there vas no clearwcut indication that performance vas best at any particular load. The pull coefficient increased slightly throughout the $20-80 \%$ slip range.

Pover number versus pull coerficicnt/slope-cljmbing abjlity

20. The relations of pover number versus pull coefficient/slopeclimbing ability for the four soil conditions are presented in figs. 20-2.3. The power requixement is higher in the loose, compactible material particulariy the $S_{1}$ and $C_{0}$ soil condition. The openmesh weel becins to pick up soil at about 20-20\% slip, particularly the loosest wet sand, and carry it inside the wheel; more and nore soil is picked up as slip increases, so that at $80 \%$ slip on the $C_{0}$ soil. concition, the whel may be carrying as much as 25 Ib of soil (see rig. 24). Fig. 25 shows the wheel at the design load operating on a $C_{0}$ soil condjtion and illustrates that there may be energy losses due to sand transportation.

21. The trapping and retention of sand vithin the whecl are tentatively attributed to cohesion or edhesion of the sand particles. Scientists at the Iunar recejving laboratory found that the Junar soju particles tended to ahere one to another during sieving operations, and so be retained on sieves vith openings much lareer than the particle size. Tt seens probable, therefore, that the open-mesh wheed mey exporience the seme problem during a lunar traverse. 


\section{Erficiency}

22. Ihe efficiency $\left(\eta^{\prime}\right)$ of the wheel did rot display an definite trends relatable to load, but the average values for a given soi.l con.dition showed a systenatic increase in efficiency with soil strencth. The total increase over the range was 30\%. This trend is in line with the assumption that notion resistance due to soil deformation increases as the soil strength decreases.

Sinlage

23. The relatjon of sinkage to sljp for the soil condition vith the smallest penctration resistance, $C_{0}$, is shown in fict. 26. The load for this test was 59 Ib.

\section{Comparative Performance of Covered and Open Whec]}

24 . Contact pressure, whecl deformation, and tire print data neasured on an unyelding surface at loads representing 50,75, 100, 125, and $150 \%$ of the desien $20 a d$ are listed in table 4 for both wheels.

Pull and torgue.

25. In general, the covered whecl developed hicher pull and torauc ot a given sip level and a higher maximum pull than did the open wheel. Both whels show the sune trends toward variations in performance vith load and soil strength. Pover number versus pul] coef.. rjeient/slope-clinbinf ability

26. The power reguirements of the two whesls at the self-propelied point on a level surface vere not apprecibly different. rhe data in tables ? and 3 and the grapic disylays incicate that the coverco whee? may be able to negotinte sloges of 25 deg or greater in the dener soils 
(vith some cohesion), while the open-mesh whecl may not. Maximum slopeclimbing abjuity of the open-inesh whecl is estimated at approximately 20 deg.

\section{Efficiency}

27. On the average, efficiencies at the $20 \%$ silig level were about the sane for both wheels, and both wheels developed the poorest efriciency on the loose, wet sand $\left(\mathrm{C}_{0}\right)$ soil condition. That the efficiency of the covered wheel may be considerably greater at higher slips is indicated in a comparison of the data shown in figs. 27 arid 28; that is, the spread between the torque-slip and pull-slip curves for a given pass is lower for the covered wheel at slips greater than about $35 \%$. Sintinge

28. It can be noted in rigs. 15 and 26 that the sinkage for the openmesh whecl was generally larger than that of the covered wheel; in fact, it was about trice as large. Repetitive trarfic

29. Trom visual observation, it was judged that the covered wheel. compacts the soil more than the open-mesh wheel does, and thus leaves a fimer material in the path over which succecding wheels travel. That is the coverea vheel's performance is inwroved on the second and third passes (the pul coefficient increases with each yass), as shom in fic̈. 27. The pull coefricient for the openanesh whecl (rig. 28) shows no definite tendency to be altered by trafric. The torque coefficient for the openwesh wheel begins to increase rapidly at slips greater than about 35\%. This increace is tentatively attributed to the larec anount of stind being throm by the whees and carried within it. 


\section{PART IV: COHCLUSIOHS}

30. The data collected and analyzed thus far are considered adequate to forn the following tentative conclusions:

a. The covered whed had greater traction and slopec]irnbing ability.

b. Power consumption rates (whr/kn) were not greatly different for the tro whels on level surfaces and slopes of: 15 deg or less.

c. Present trends in the analysis indicate that power efficiency ma be much lower for the open-mesh wheel than for the covered wheel at slips greater than 55 percent.

d. In general, the data indicate that the wheels did not perform any better at one load than at another.

e. On the $C_{0}$ soil condition, the covered wheel showed a tendency to improve performance on the second and third passes in the same path, whereas the open-mesh wheel did not. 
Table 1. Soil Test Results (Before Traffic)

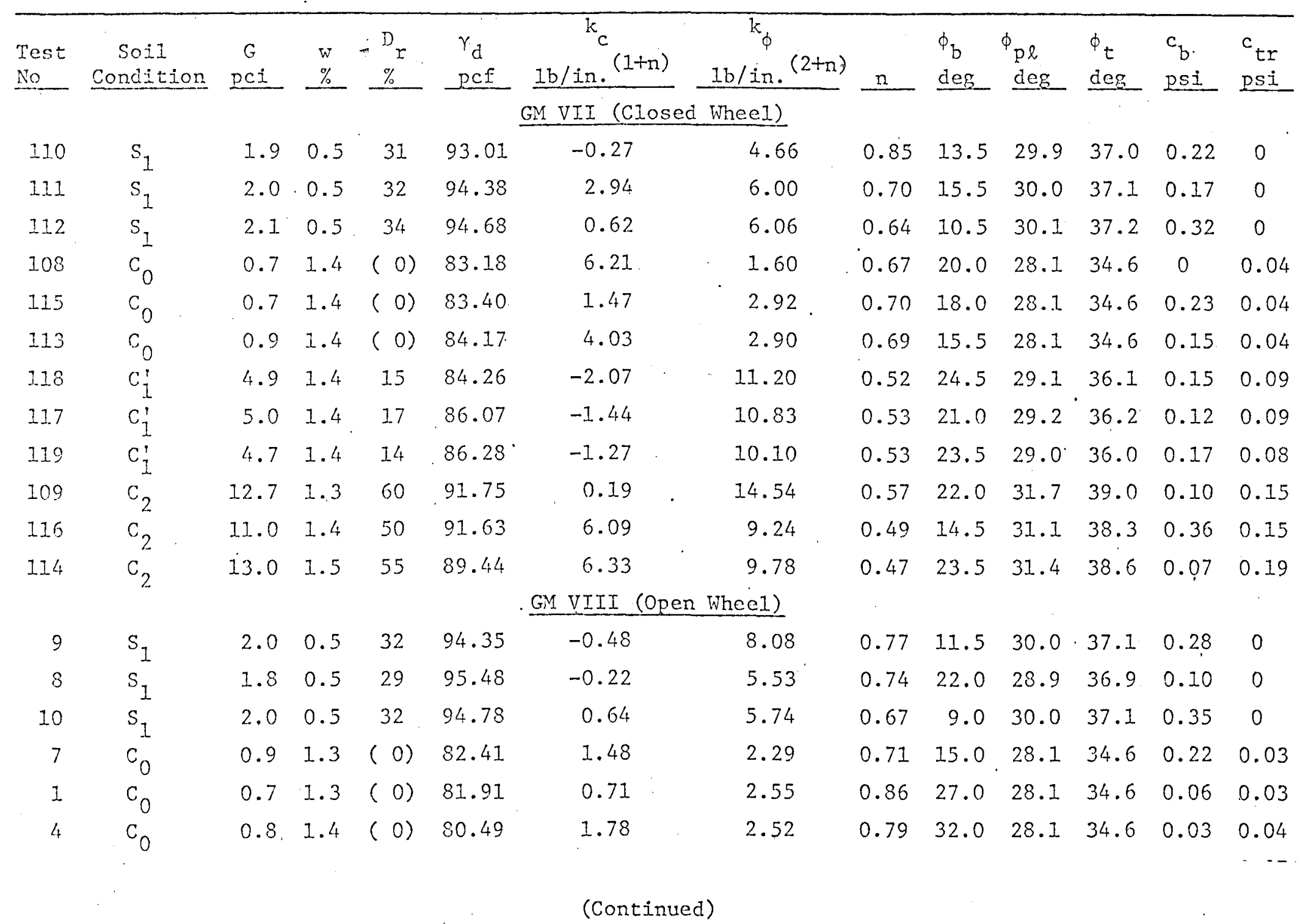


Table 1 (Concluded)

\begin{tabular}{|c|c|c|c|c|c|c|c|c|c|c|c|c|c|}
\hline $\begin{array}{l}\text { Test } \\
\text { No } \\
\end{array}$ & $\begin{array}{c}\text { Soit } \\
\text { Condition }\end{array}$ & $\begin{array}{c}G \\
n c i\end{array}$ & $\begin{array}{l}W \\
\% \\
\end{array}$ & $\begin{array}{l}-\mathrm{D}_{\mathrm{r}} \\
\% \\
\end{array}$ & $\begin{array}{r}Y_{d} \\
p c f \\
\end{array}$ & $1 \mathrm{~b} / \mathrm{in} .{ }_{\mathrm{c}}^{\mathrm{k}_{\mathrm{C}}(1+\mathrm{n})}$ & $\begin{array}{c}k_{\phi} \\
1 \mathrm{~b} / \mathrm{in} .(2+\mathrm{n}) \\
\end{array}$ & $\mathrm{n}$ & $\begin{array}{l}\phi_{\mathrm{b}} \\
\mathrm{deg}\end{array}$ & $\begin{array}{l}\phi p \ell \\
\text { deg }\end{array}$ & $\begin{array}{l}\phi t \\
\mathrm{deg} \\
\end{array}$ & $\begin{array}{l}c_{b} \\
\text { psi }\end{array}$ & $\begin{array}{l}c_{\text {tr }} \\
\text { psi }\end{array}$ \\
\hline 12 & $C_{i}^{\prime}$ & 4.3 & 1.4 & 9 & 84.76 & 2.23 & 5.03 & 0.65 & 18.0 & 28.6 & 35.7 & 0.29 & 0.07 \\
\hline 3 & $C_{1}^{\prime}$ & 4.7 & 1.3 & 17 & 86.36 & 1.95 & 5.32 & 0.71 & 30.0 & 29.2 & 36.2 & 0.12 & 0.07 \\
\hline 5 & $C_{i}^{1}$ & 4.3 & 1.3 & 13 & 87.70 & 1.87 & 5.69 & 0.66. & 23.5 & 28.9 & 36.0 & 0 & 0.07 \\
\hline 13 & $\mathrm{C}_{2}$ & 11.1 & 1.4 & 51 & 91.64 & 3.01 & 10.38 & 0.54 & 10.0 & 31.0 & 38.4 . & 0.35 & 0.15 \\
\hline 2 & $\mathrm{C}_{2}$ & 10.8 & 1.4 & 49 & 90.30 & 7.79 & 7.40 & 0.54 & 9.0 & 31.0 & 38.1 & 0.52 & 0.15 \\
\hline 11 & $\mathrm{C}_{2}$ & 11.4 & 1.6 & 45 & 91.70 & 6.40 & 9.13 & 0.53 & 11.5 & 30.7 & 37.8 & 0.44 & 0.19 \\
\hline
\end{tabular}




\begin{tabular}{|c|c|c|c|c|c|c|c|c|c|c|c|c|c|c|}
\hline \multirow[b]{2}{*}{$\begin{array}{l}\text { Test } \\
\text { No. } \\
\end{array}$} & \multirow{2}{*}{$\begin{array}{c}\text { Soil } \\
\text { Condition } \\
\end{array}$} & \multicolumn{2}{|r|}{+} & \multirow{2}{*}{$\frac{\text { Load }}{\mathrm{N}}$} & \multirow{3}{*}{$\frac{W}{1 \mathrm{~b}}$} & \multicolumn{2}{|c|}{$\begin{array}{c}\text { Contact Pres- } \\
\text { sure } P_{C} \\
\end{array}$} & \multirow[b]{2}{*}{$\mathrm{P}_{20} / \mathrm{W}$} & \multirow[b]{2}{*}{$\mathrm{M}_{20} / \mathrm{W}$} & \multirow[b]{2}{*}{$n_{20}^{\prime}$} & \multirow{2}{*}{$\mathrm{PN}_{\mathrm{sp}}^{*}$} & \multirow{2}{*}{$\mathrm{PN}_{\max }^{* \%}$} & \multirow[b]{2}{*}{$\mathrm{PN}_{15}^{\dagger}$} & \multirow[b]{2}{*}{$\mathrm{PN}_{25}^{\dagger}$} \\
\hline & & $\mathrm{MN} / \mathrm{m}^{3}$ & $\mathrm{pci}$ & & & $\mathrm{kN} / \mathrm{m}^{2}$ & psi & & & & & & & \\
\hline \multicolumn{14}{|c|}{ First Pass } & \\
\hline $69-110$ & $s_{1}$ & 0.52 & 1.9 & 195 & 44 & 6.9 & 1.00 & 0.37 & 0.54 & 0.55 & 0.12 & 0.62 & 0.47 & $\infty$ \\
\hline-111 & $s_{1}$ & 0.54 & 2.0 & 260 & 59 & 7.3 & 1.06 & 0.39 & 0.54 & 0.58 & 0.10 & 0.58 & 0.46. & $\infty$ \\
\hline-1.12 & $s_{1}$ & 0.57 & 2.1 & 325 & 73 & 7.7 & 1.12 & 0.36 & 0.53 & 0.54 & 0.16 & 0.70 & 0.55 & $\infty$ \\
\hline-108 & $\mathrm{C}_{0}$ & 0.19 & 0.7 & 195 & 44 & 6.9 & 1.00 & 0.33 & 0.52 & 0.51 & 0.04 & 0.74 & 0.50 & $\infty$. \\
\hline-115 & $c_{0}$ & 0.20 & 0.7 & 260 & 59 & 7.3 & 1.06 & 0.36 & 0.55 & 0.52 & 0.14 & 0.78 & 0.54 & $\infty$ \\
\hline-113 & $\mathrm{C}_{0}$ & 0.23 & 0.9 & 32.5 & 73 & 7.7 & 1.12 & 0.36 & 0.57 & 0.51 & 0.18 & 0.66 & 0.50 & $\infty$ \\
\hline-1128 & $C_{i}^{\prime}$ & 1.31 & 4.9 & 195 & $44^{\circ}$ & 6.9 & 1.00 & 0.51 & 0.62 & 0.66 & 0.06 & 0.66 & 0.36 & 0.57 \\
\hline-117 & $C_{i}$ & 1.34 & 5.0 & 260 & 59 & 7.3 & 1.06 & 0.52 & .0 .61 & 0.68 & 0.06 & 0.77 & 0.38 & 0.60 \\
\hline-119 & $C_{I}^{i}$ & I. 28 & 4.7 & 325 & 73 & 7.7 & 1.12 & 0.49 & 0.58 & 0.68 & 0.08 & 0.66 & 0.36 & 0.54 \\
\hline-109 & $\mathrm{C}_{2}$ & 3.44 & 12.7 & 195 & 44 & 6.9 & 1.00 & 0.52 & 0.62 & 0.67 & 0.06 & .0 .70 & 0.38 & 0.60 \\
\hline-116 & $\mathrm{C}_{2}$ & 2.95 & 11.0 & 260 & 59 & 7.3 & 1.06 & 0.47 & 0.60 & 0.63 & 0.10 & 0.80 & 0.46 & 0.72 \\
\hline-114 & $\mathrm{C}_{2}$ & 3.50 & 13.0 & 325 & 73 & $7.7^{\circ}$ & 1.12 & 0.49 & 0.63 & 0.62 & 0.10 & 0.76 & 0.43 & 0.65 \\
\hline \multicolumn{15}{|c|}{ Second Pass } \\
\hline-115 & $\mathrm{C}_{0}$ & 0.78 & 2.9 & 260 & 59 & 7.3 & 1.06 & 0.48 & 0.61 & 0.63 & 0.12 & 0.81 & 0.50 & 0.78 \\
\hline \multicolumn{15}{|c|}{ Third Pass } \\
\hline-115 & $\mathrm{C}_{0}$ & 0.74 & 2.7 & 260 & 59 & 7.3 & 1.06 & 0.50 & 0.61 & 0.66 & 0.06 & 0.73 & 0.43 & 0.69 \\
\hline
\end{tabular}

* Power number at self-propelled point.

Power number at point where the rate of increase in power number rapidly increases.

tpower numbers for $15-$ and 25 -deg slopes, respectively (o denotes inability to climb).
NOTE: To compute power consumption rate (PCR) in whr $/ \mathrm{km} /$ wheel on a given slope, e.g. $15 \mathrm{deg}$, calculate:

$\mathrm{PCR}=\mathrm{PN}_{15} \times \frac{1000}{3600} \times$ wheel load (in newtons) 
Table 3. Results of Tests with the GM VIII (Open) WheeI

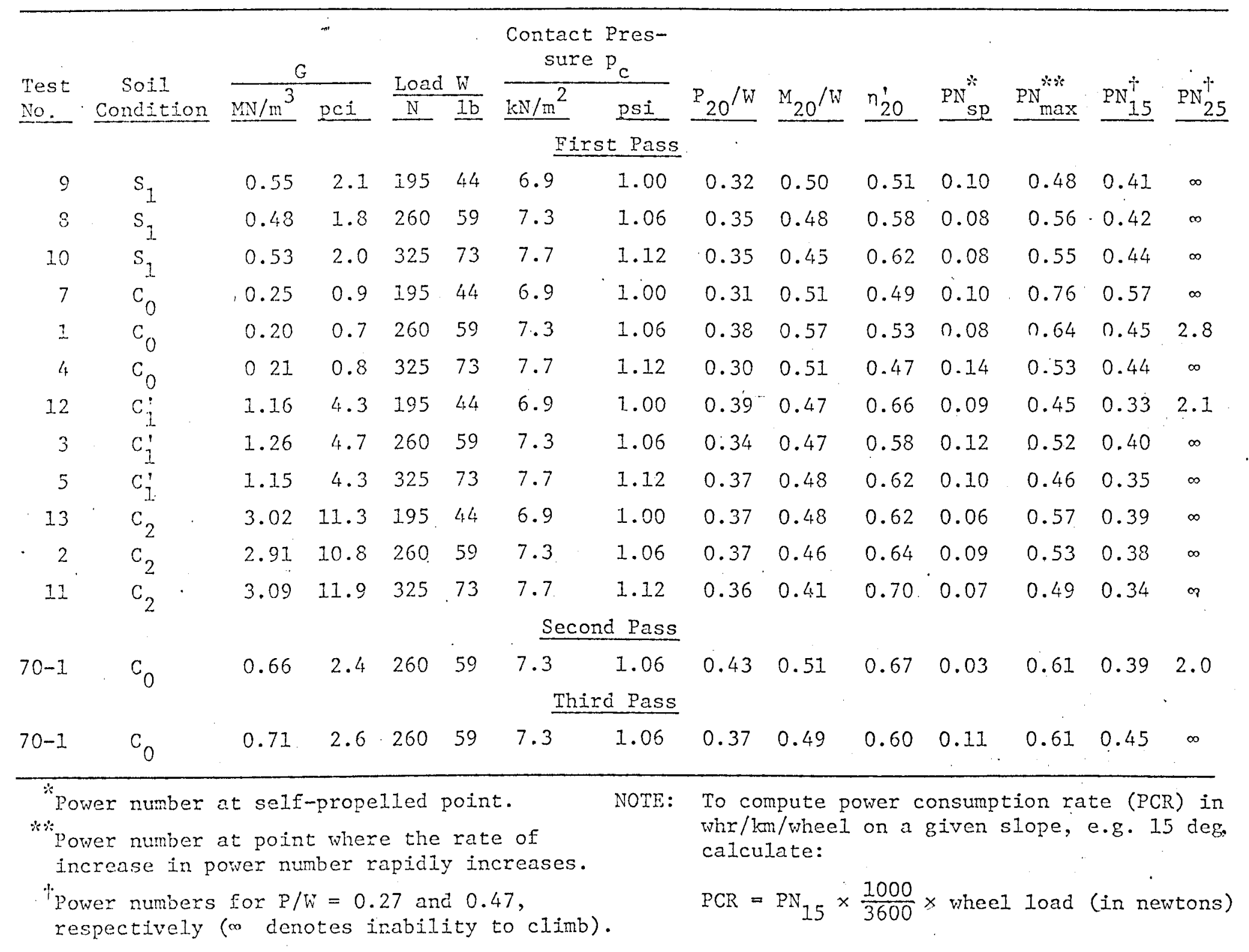


Table 4. Tire Data"

\begin{tabular}{|c|c|c|c|c|c|c|c|c|c|c|c|c|}
\hline \multicolumn{2}{|c|}{ Deflection } & \multirow{2}{*}{$\begin{array}{l}\text { Load } \\
\text { Ib }\end{array}$} & \multirow{2}{*}{$\begin{array}{c}\text { Carcass } \\
\text { Dian- } \\
\text { eter } \\
\text { in. }\end{array}$} & \multicolumn{2}{|c|}{$\begin{array}{l}\text { Section } \\
\text { Height } \\
\text { in. }\end{array}$} & \multicolumn{2}{|c|}{$\begin{array}{c}\text { Section } \\
\text { Width } \\
\text { in. }\end{array}$} & \multirow{2}{*}{$\begin{array}{l}\text { Measured } \\
\text { Rolling } \\
\text { Circum- } \\
\text { ference } \\
\quad f t \\
\end{array}$} & \multirow{2}{*}{$\begin{array}{c}\text { Contact } \\
\text { Area } \\
\text { sq in. }\end{array}$} & \multicolumn{2}{|c|}{$\begin{array}{c}\text { Tire Print } \\
\text { in. }\end{array}$} & \multirow{2}{*}{$\begin{array}{c}\text { Contact } \\
\text { Pressure } \\
\quad \text { psi } \\
\end{array}$} \\
\hline $\begin{array}{c}\text { computed } \\
\text { in. } \\
\end{array}$ & $\%^{* * *}$ & & & Loaded & Unloaded & Loaded & Unloaded & & & Length & Width & \\
\hline & & & . & & GM VII & I (Close & d) Wheel & & & & & \\
\hline 0.85 & 5.3 & 29.23 & 32.01 & 6.44 & 7.29 & 9.90 & 9.45 & & 32.97 & 7.45 & 5.30 & 0.90 \\
\hline 1.19 & 7.4 & 43.84 & 32.01 & 6.11 & 7.29 & 10.10 & 9.45 & 7.569 & 44.12 & 9.03 & 6.23. & 1.00 \\
\hline 1.46 & 9.1 & 58.45 & 32.01 & 5.83 & 7.24 & 10.43 & 9.45 & 7.539 & 55.26 & 9.82 & 6.85 & $1.06^{\circ}$ \\
\hline 1.76 & 11.0 & 73.07 & 32.01 & 5.53 & 7.29 & 10.74 & 9.45 & 7.060 & 65.84 & 10.58 & 7.40 & 1.12 \\
\hline 2.10 & 13.1 & 87.68 & 32.01 & 5.19 & 7.29 & 1.1 .15 & 9.45 & & 71.14 & 10.95 & 7.93 & 1.23 \\
\hline & & & & & GM VI & Cope & Wheel & & & & & \\
\hline 1.23 & 7.6 & 29.23 & 32.32 & 6.21 & $\cdot 7.44$ & 10.00 & $9.15^{\circ}$ & & 54.87 & 10.08 & 6.58 & 0.54 \\
\hline 1.66 & 10.3 & 43.84 & 32.32 & 5.79 & 7.44 & 10.36 & 9.15 & 7.211 & 59.80 & 10.73 & 6.44 & 0.74 \\
\hline 2.11 & 13.0 & 58.45 & 32.32 & 5.34 & 7.44 & 10.72 & 9.15 & 7.060 & 76.57 & 11.75 & 7.74 & 0.77 \\
\hline 2.37 & 14.7 & 73.07 & 32.32 & 5.08 & 7.44 & 11.10 & 9.15 & 6.778 & 90.60 & 12.15 & 8.80 & 0.81 \\
\hline 2.62 & 16.2 & 87.68 & 32.32 & 4.83 & 7.44 & 11.52 & 9.15 & & 101.84 & 13.25 & 9.13 & 0.87 \\
\hline
\end{tabular}

*All data given represent an average of two measurements at diametrically opposite positions. * Deflection $\%=(2 \delta / d) \times 100$. 


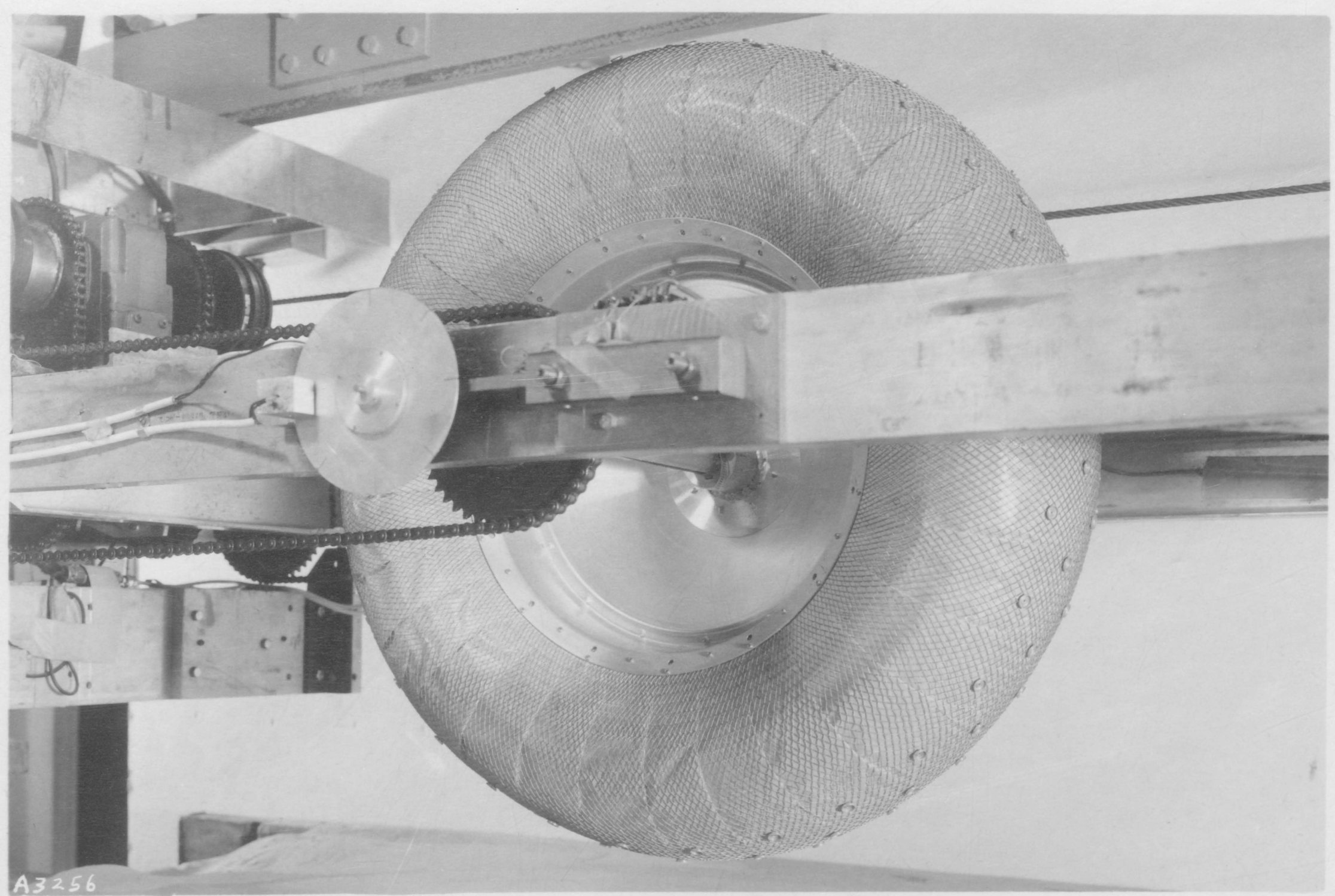

Fig. 1a. Fabric-covered wheel (GM VII) 


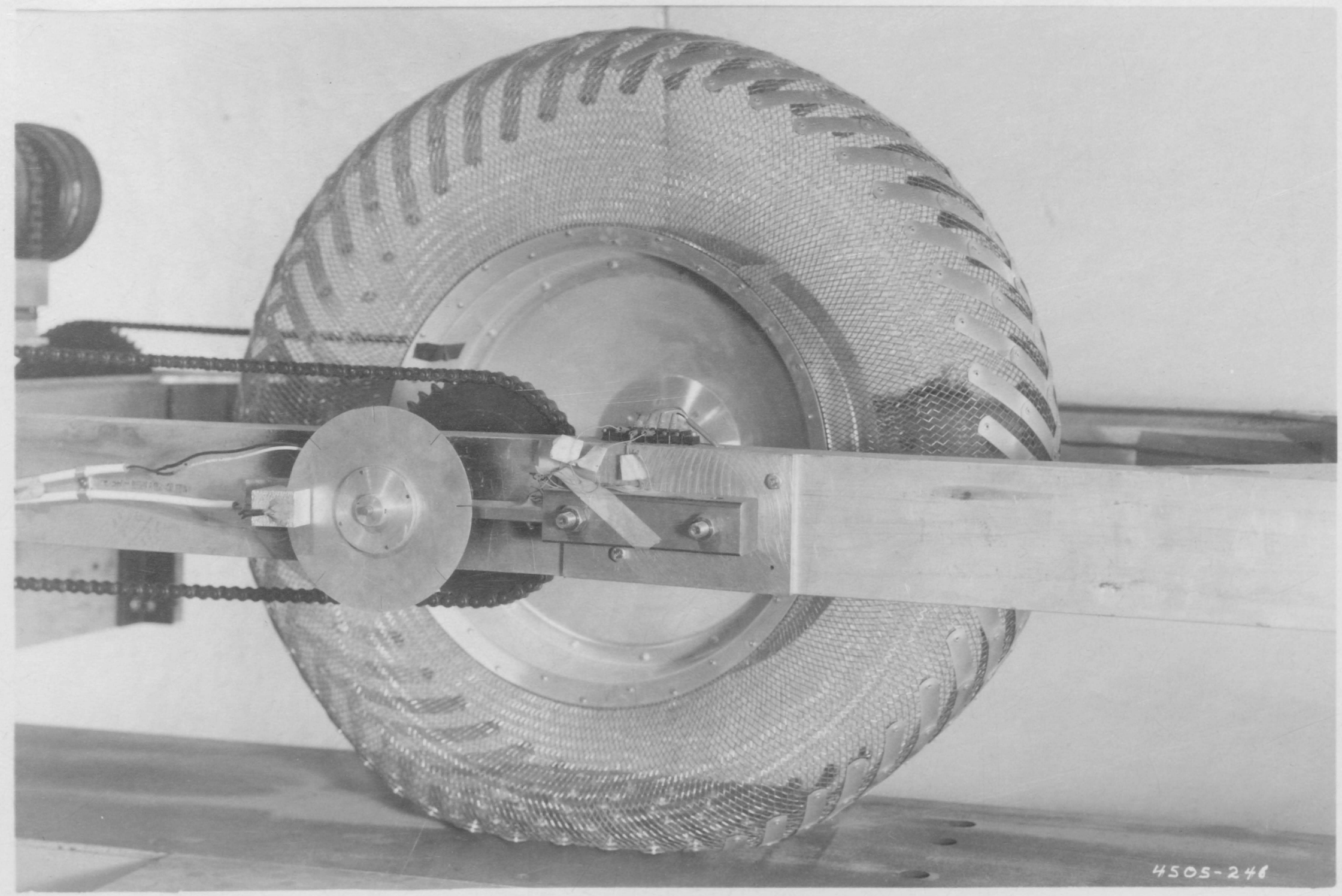

Fig. 1b. Open-mesh wheel (GM VIII) 
U STANDATO SIEVE OPENING IN INCHES U.S. STANDARD SIEVE NUMBERS

HYDROMETER

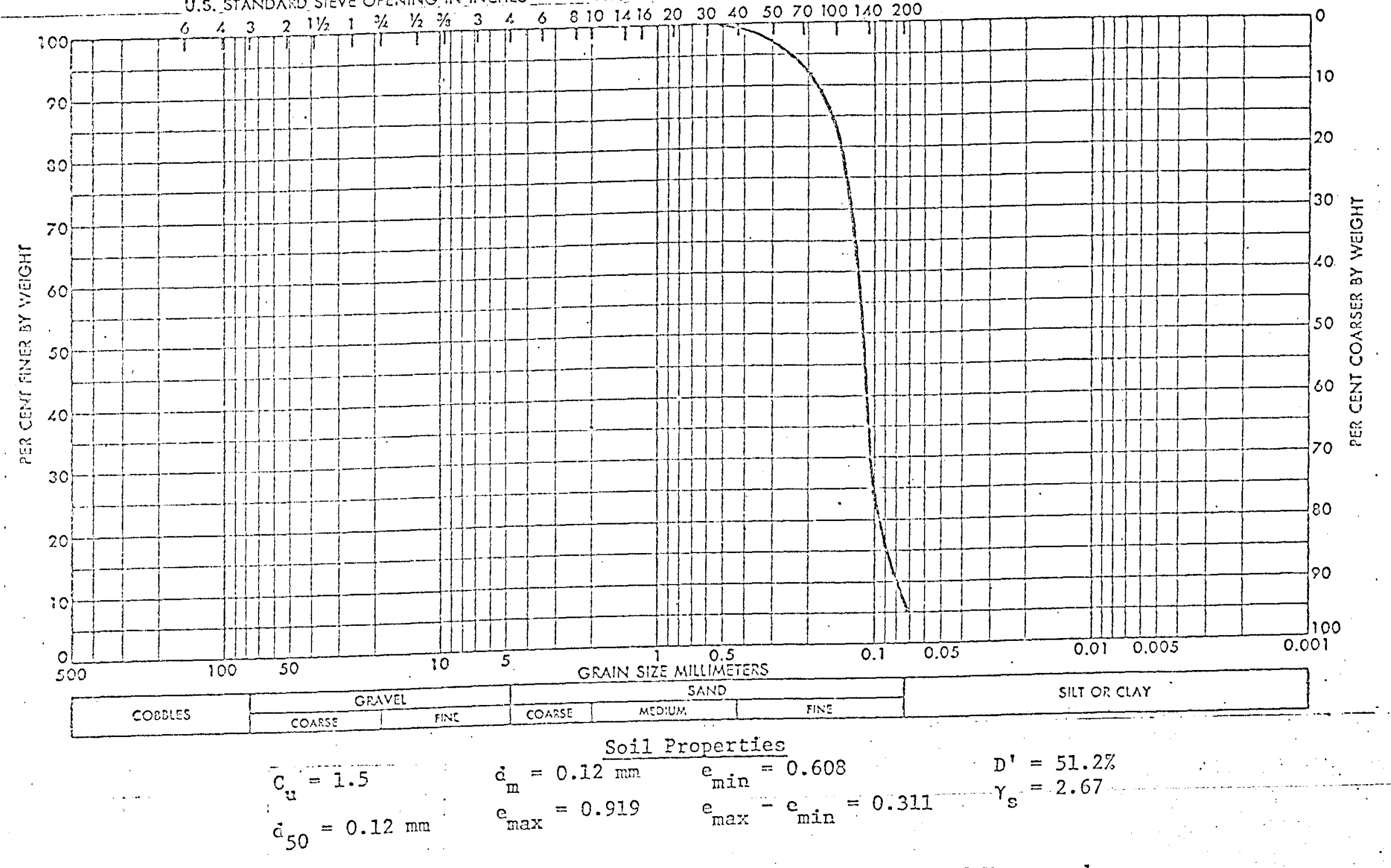

Fig. 2. Grain-size distribution and soil properties of Yuma sand 


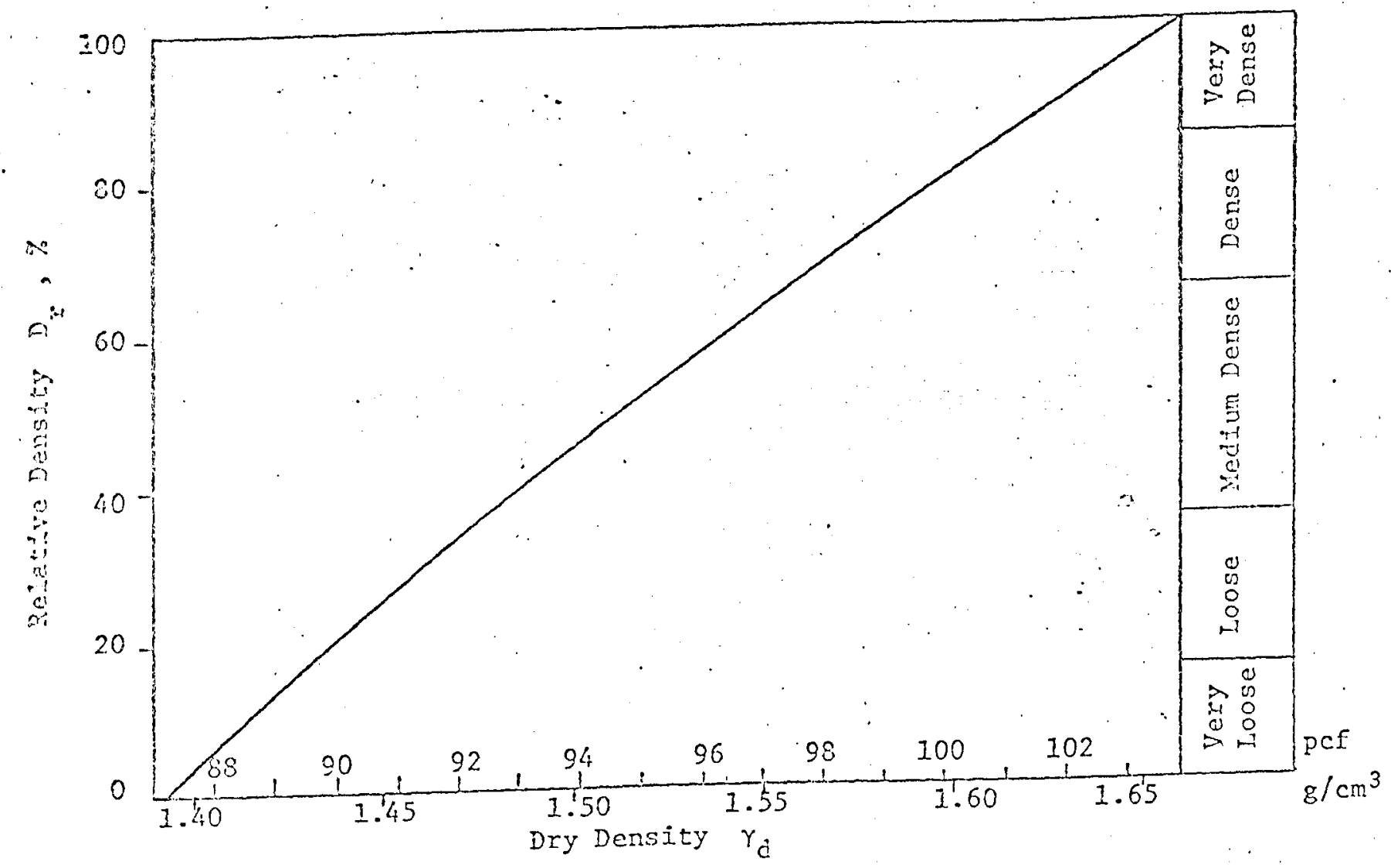

$$
\begin{aligned}
& \gamma_{\mathrm{d} \min }=1.39 \mathrm{~g} / \mathrm{cm}^{3}(87 \mathrm{pcf}) \\
& \gamma_{\mathrm{d} \max }=1.66 . \mathrm{g} / \mathrm{cm}^{3} \quad(104 \mathrm{pcf})
\end{aligned}
$$

Fig. 3. Relation between dry density $\gamma_{d}$ and relative density $D_{r}$ of Yuma sana 


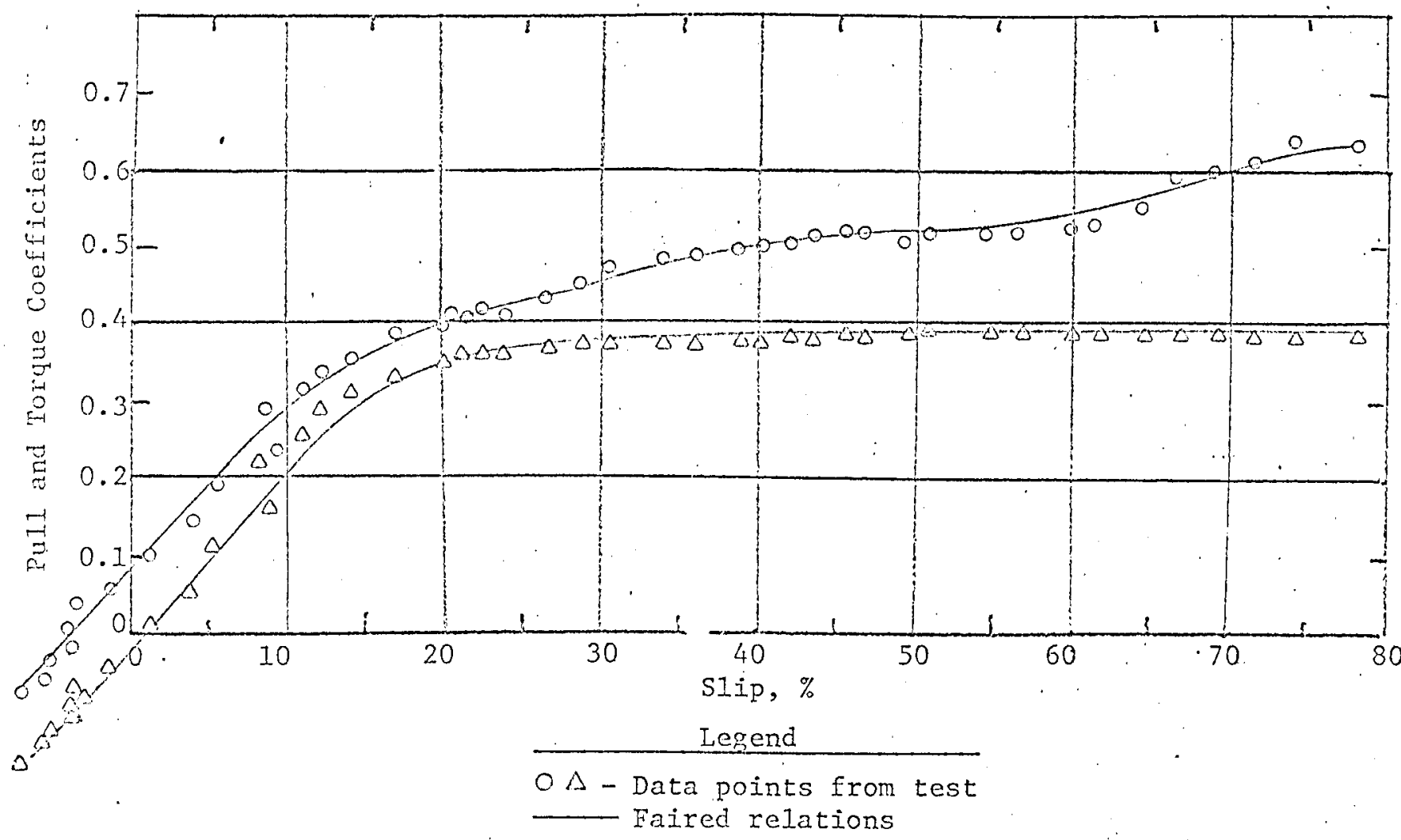

Fig. 4. Representative relations of pull and torque coefficients to slip for the open mesh wheel (GM VIII); wet sand $C_{I}^{\prime}$; $G \approx 4.9$ psi $/$ in. $c=0.09$ psi $w=1.4 \% ; \operatorname{Load}=591 \mathrm{~b}$ 


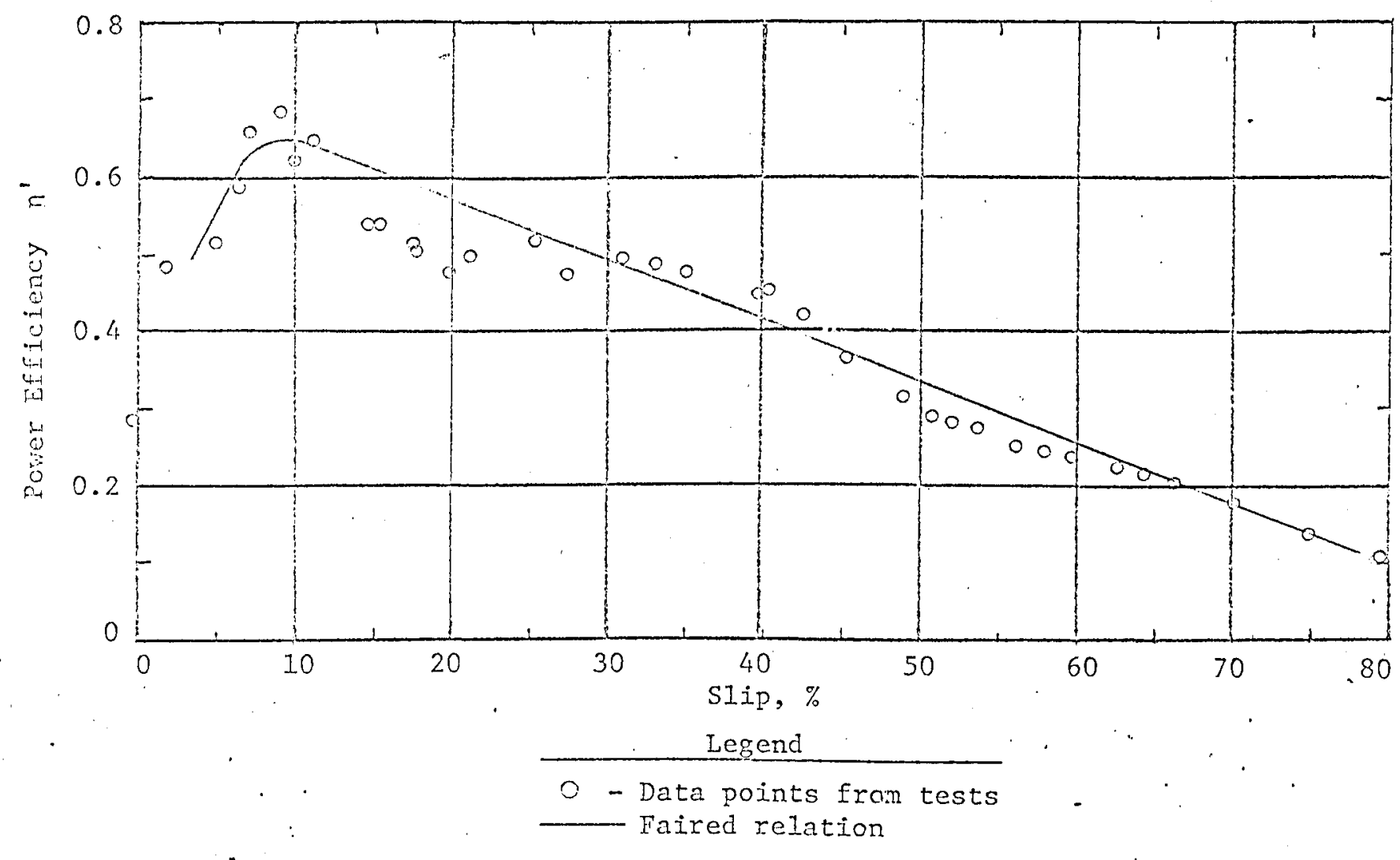

Fig. 5. Representative relations of power efficiency to slip for the open mesh wheel (GM VIII) Wet sand $C_{0} ; G \approx 0.8 \mathrm{psi} / \mathrm{in} . ; c=0.04 \mathrm{psi} ; \mathrm{w}=1.4 \% ; 10 \mathrm{ad}=59 \mathrm{lb}(260 \mathrm{~N})$ 

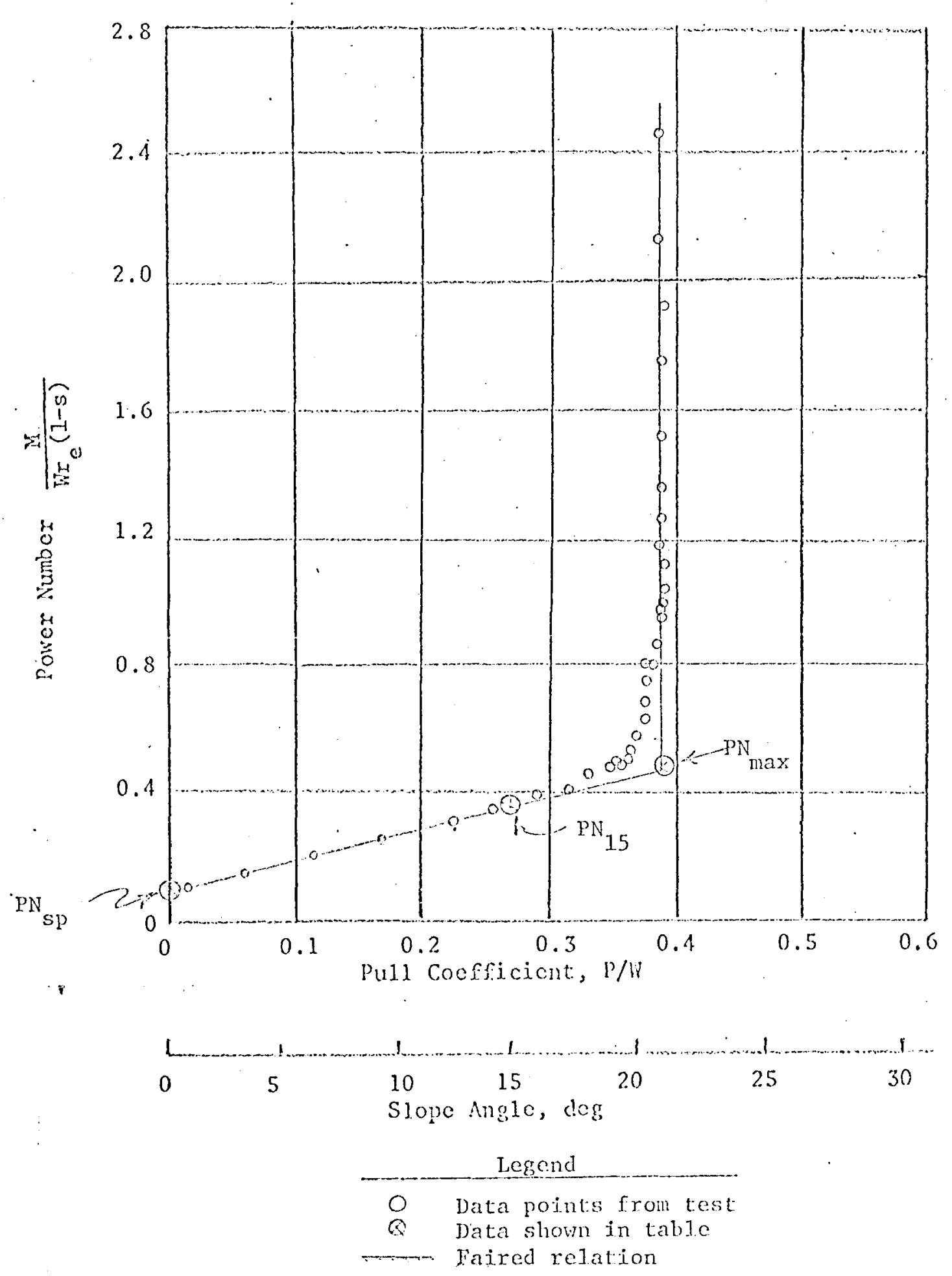

Fjg. 6. Representative relations of power number to pul1 coefficient for the open mesh wheel (GM VIII); wet sanci $C_{0} ; G \approx 0.8$ psi/in.; $c=0.04$ psi; 


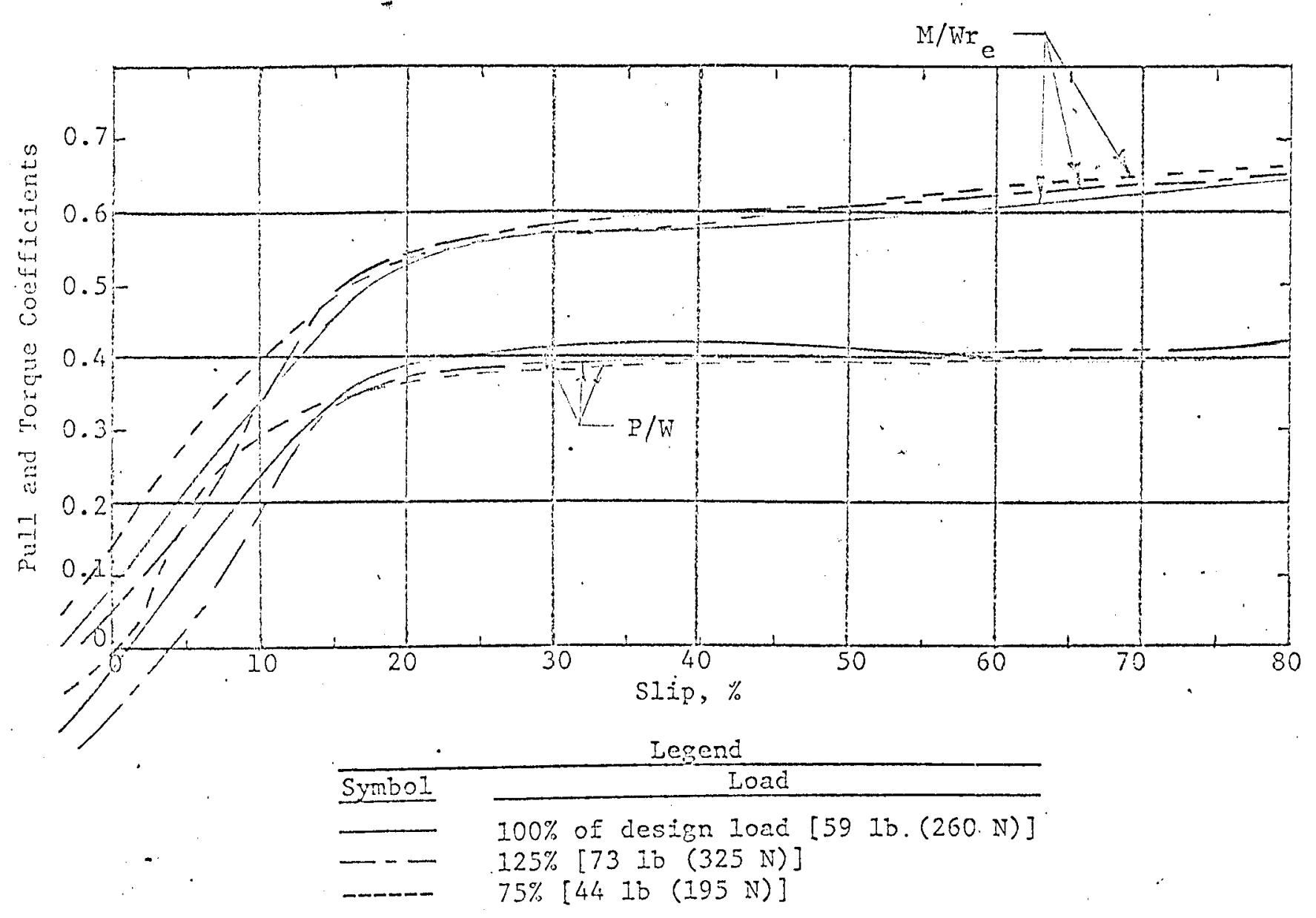

$\underset{\infty}{\infty}$

ary

ind

Fig. 7. PuII and torque coefficients versus slip for the fabric-covered wheel (GM VII); Air dry sand $S_{1} ; G \approx 2.0$ psi/in.; $c=0.0$ psi; $w=1.5 \%$ 


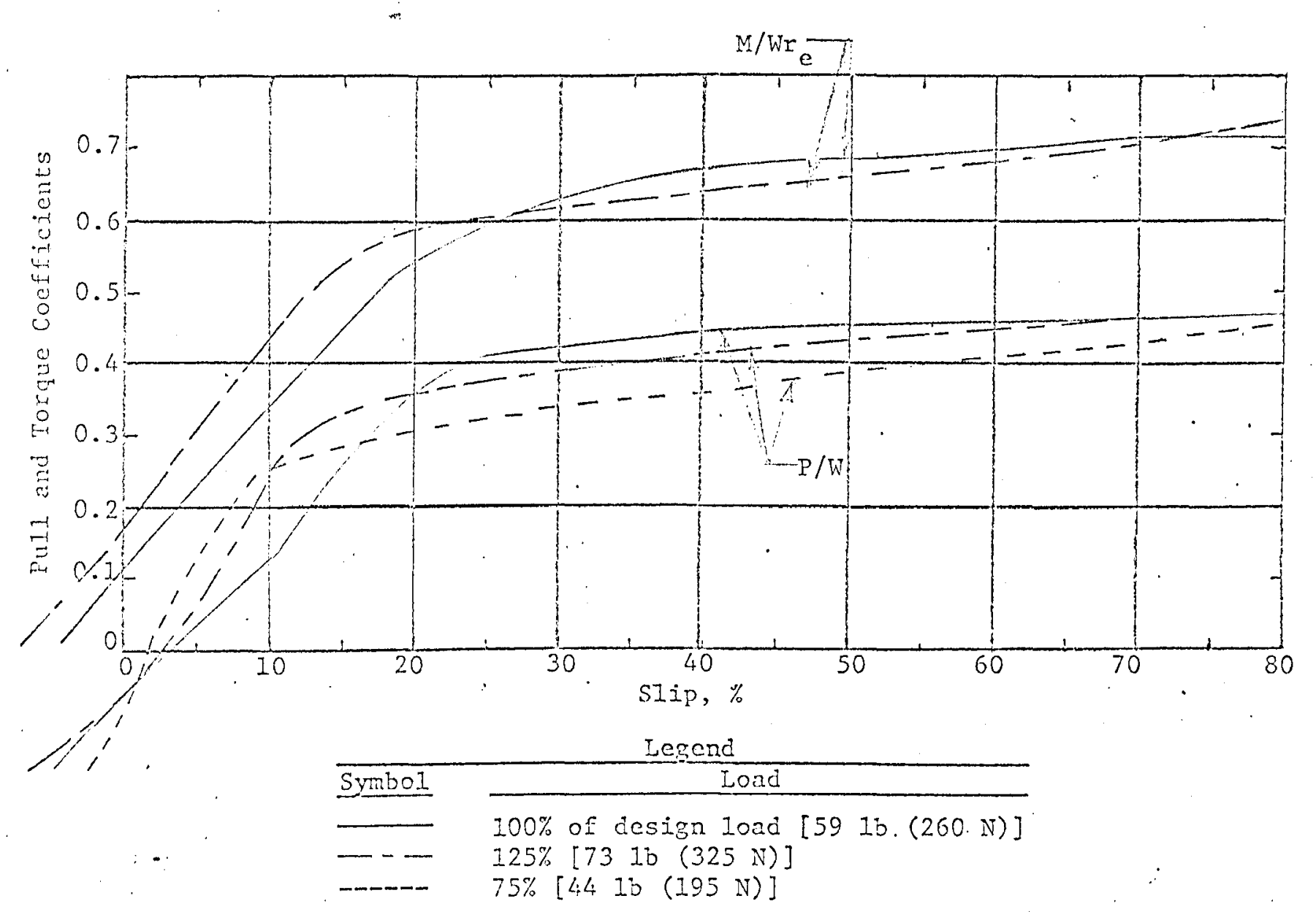

Fig. 8. PuII and torque coefficients versus slip for the fabric-covered (GM VIII); wet sand $C_{0} ; G \cong 0.8$ psi/in.; $c=0.04$ psi; $w=1.4 \%$ 


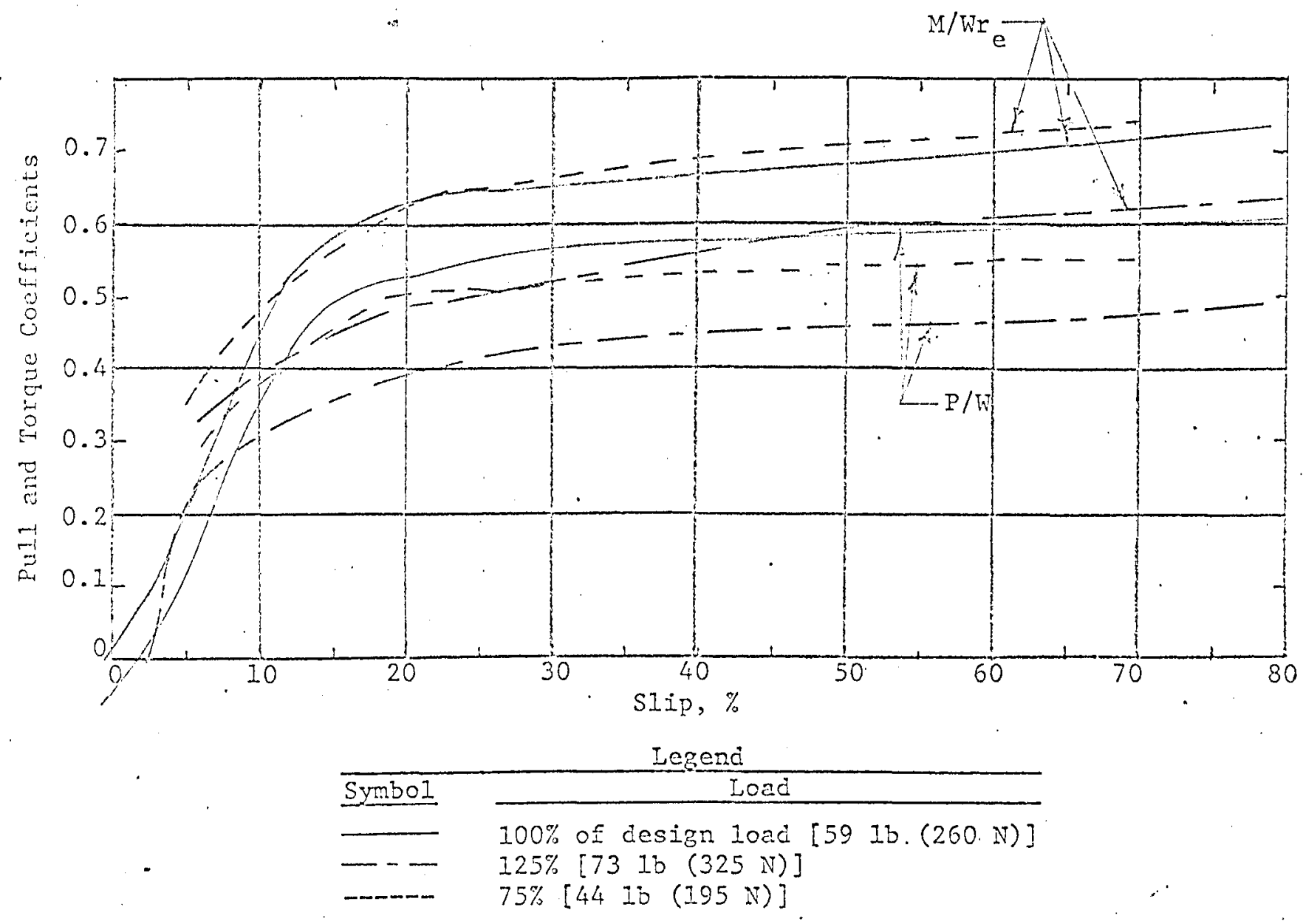

Fig. 9. PuIl and torque coefficients versus slip for the fabric-covered wheeI (GM VII); wet sand $C_{1}^{\prime} ; G \approx 4.9$ psi/in.; $c=0.09$ psi; $w=1.4 \%$ 


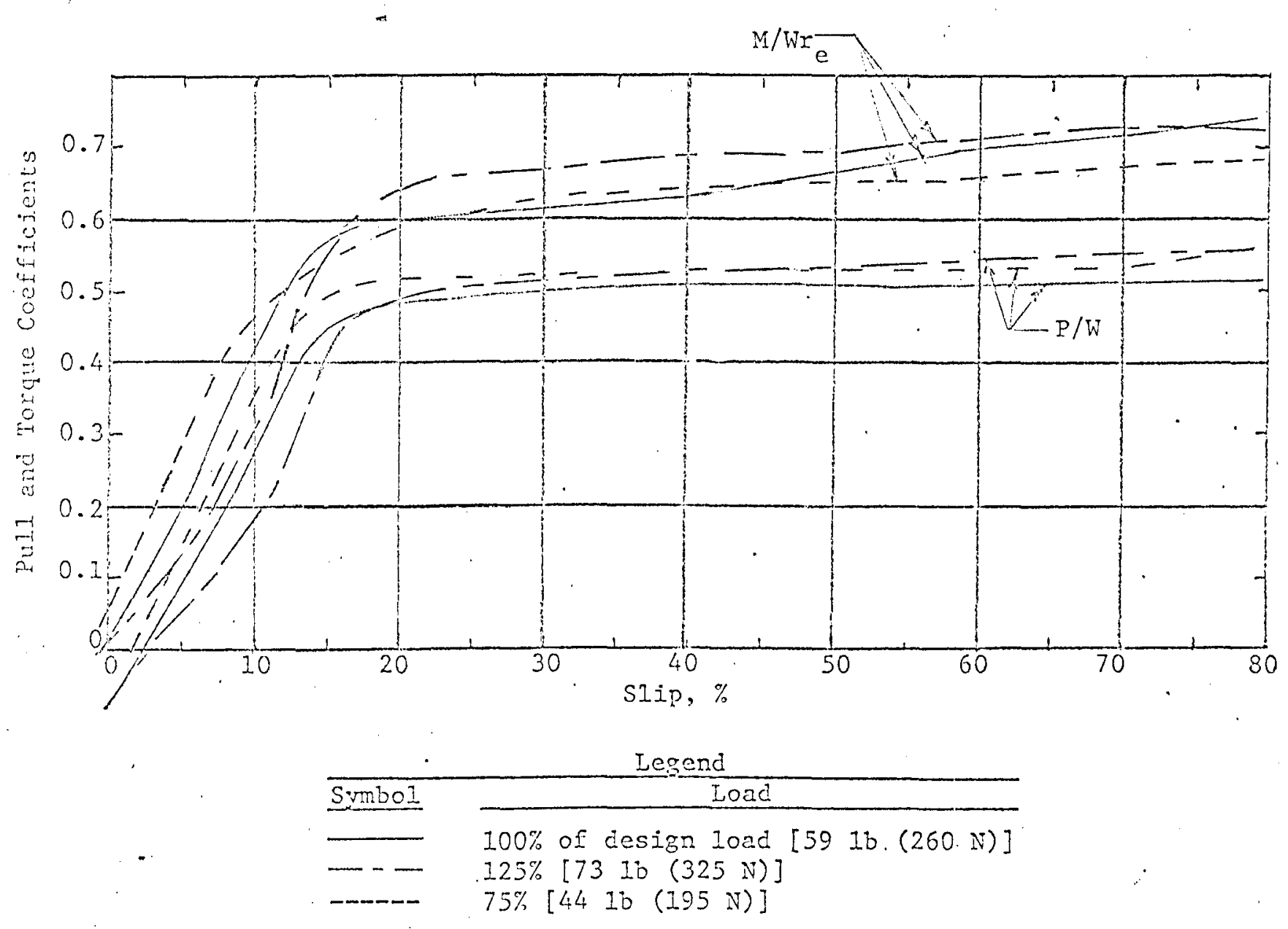

Fig: 10. Pull and torque coefficients versus slip for the fabric-covered wheel (GM VII): wet sand $C_{2} ; G \approx 12.0$ psi/in.; $c=0.16$ psi; $w=1.4 \%$ 

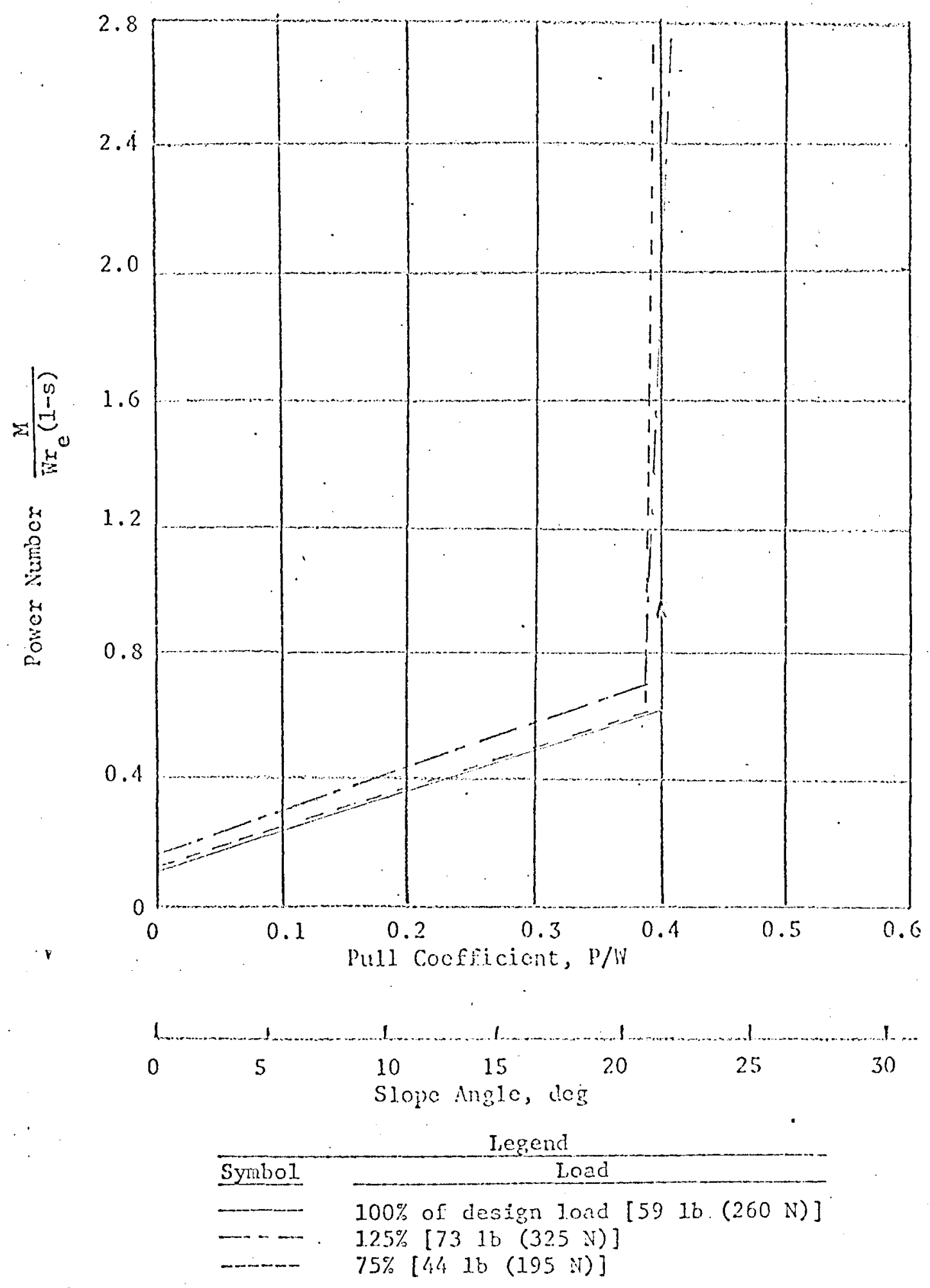

Fig. 1.1. Power number versus pull coefficient for the fabric-covered whoel. (GH VII) dry sand $\bar{S}_{1} ; G:=2 \mathrm{ps} / \mathrm{in}$; $c=0.0 \mathrm{psi}$ 

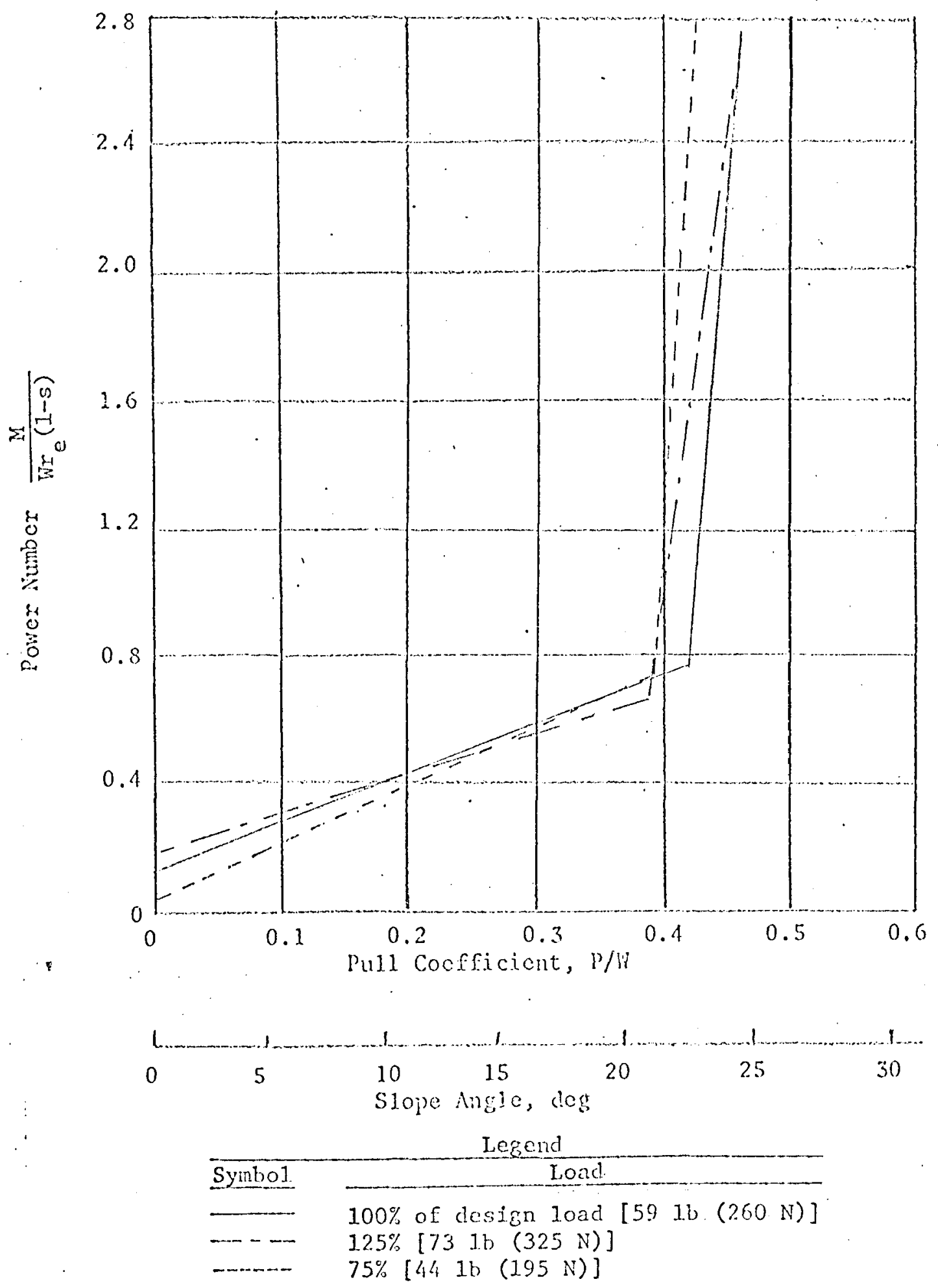

Fig. 12. Power number versus pull coefficient for the fabric-covered whee]. (GM VII); wet sand $C_{0} ; G:: 0.8$ psi/in ; $c=0.04 \mathrm{psi} ; \quad=1.4{ }^{\circ}$ 


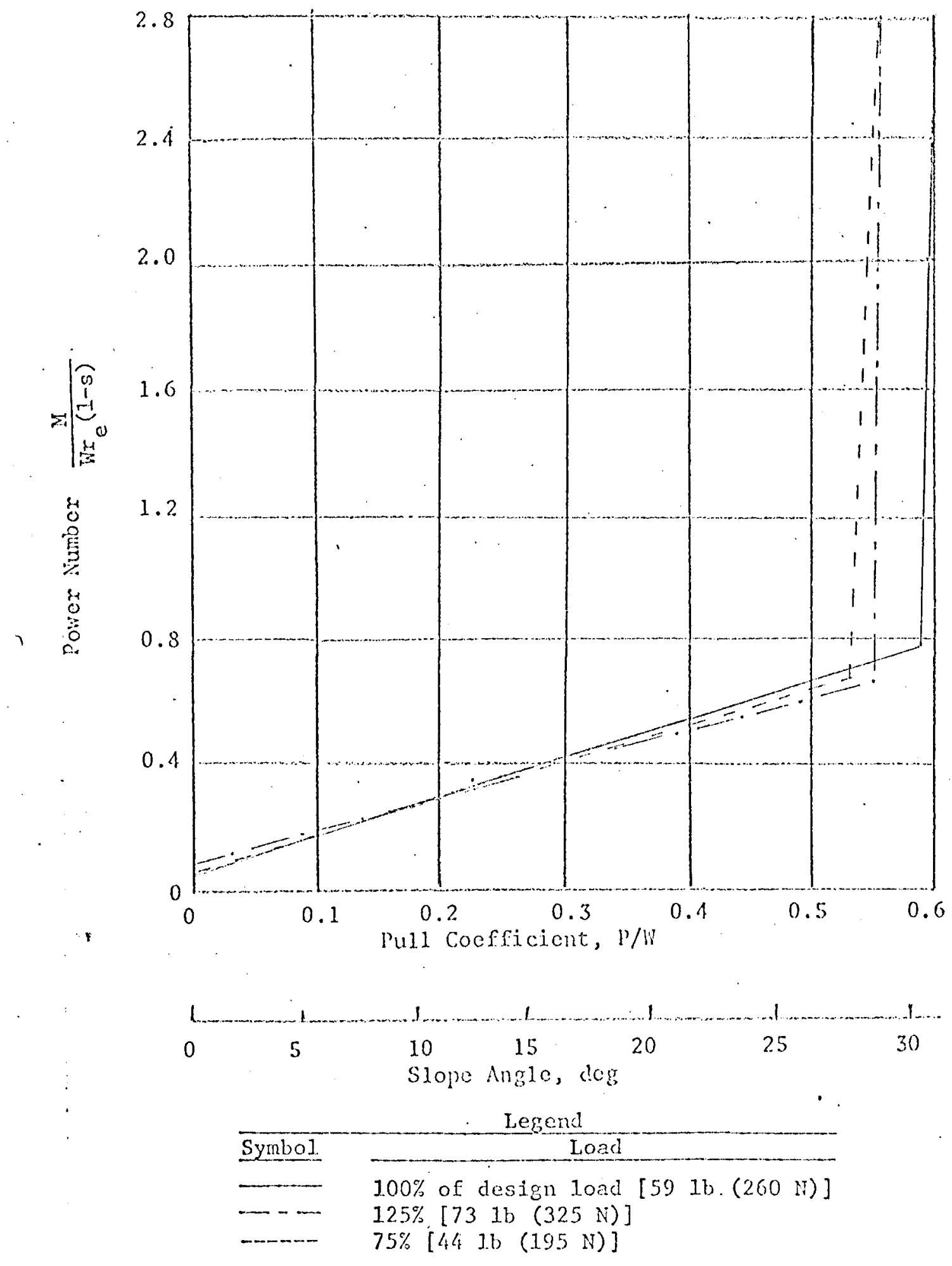

Fig. 13. Power nuber versus pull coefficient for the fabric-covered wheel (GM VT.J); wet sand $C_{1}^{\prime} ; G^{\prime}=4.9$ psilin.;

$$
c .=0.09 \text { psi.: } w=1.4 \%
$$



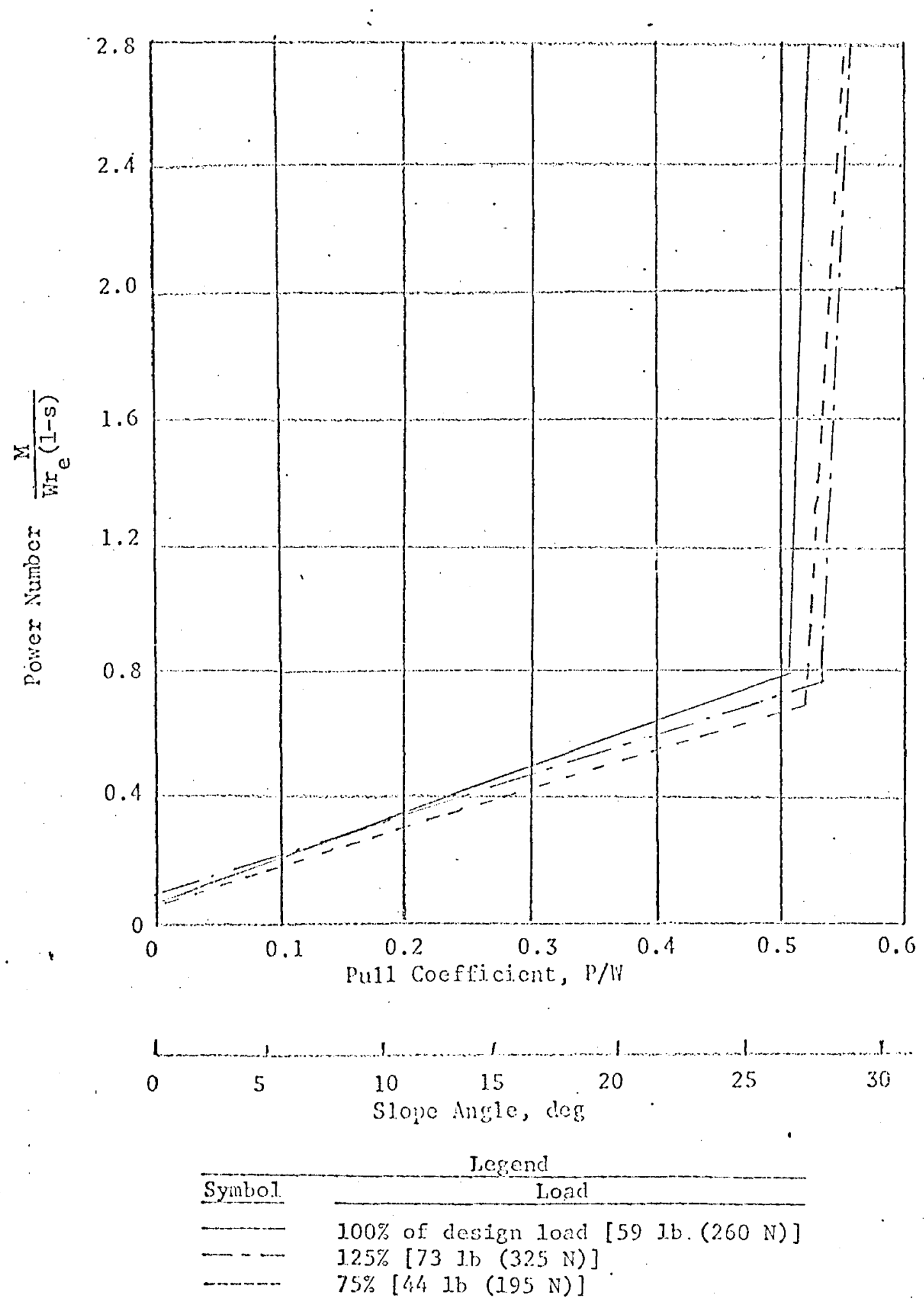

Fig. 14. Pover number versus pull coefficient for the fabric-covered wheel (Gi. VIT); wet sand $C_{2} ; G 12.0$ psi/in.;

$$
c=0.16 \mathrm{ps}: \mathrm{w}:=1.4 \%
$$




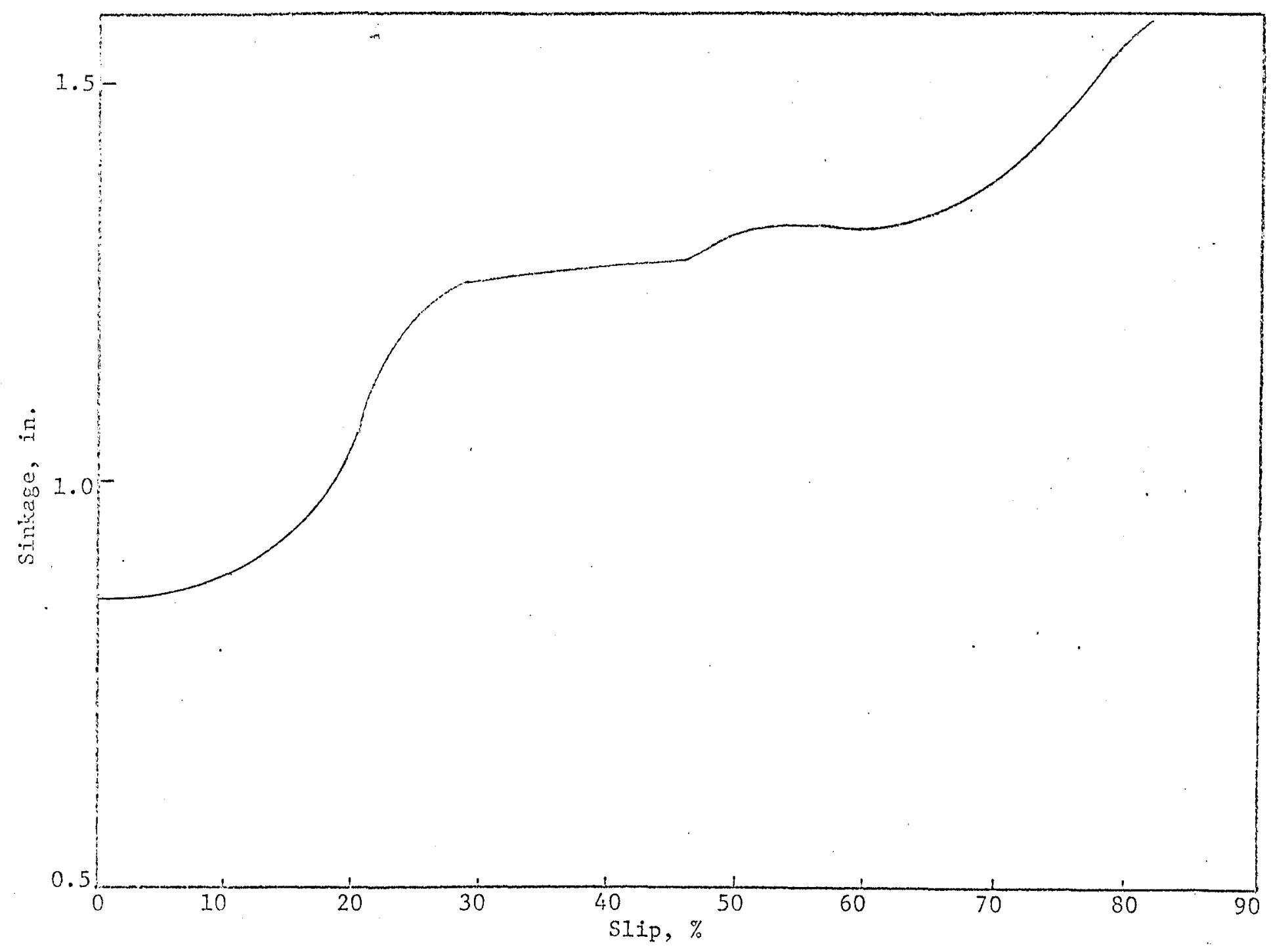

Fig. 15. Sinkage versus slip for the fabric-covered wheel (GM VII); wet sand $C_{0}: G \approx 0.8 \mathrm{psi} / \mathrm{in} . ; \mathrm{c}=0.04 \mathrm{psi}$ $\mathrm{w}=1.4 \% ;$ load $=59 \mathrm{lb}(260 \mathrm{~N})$ 


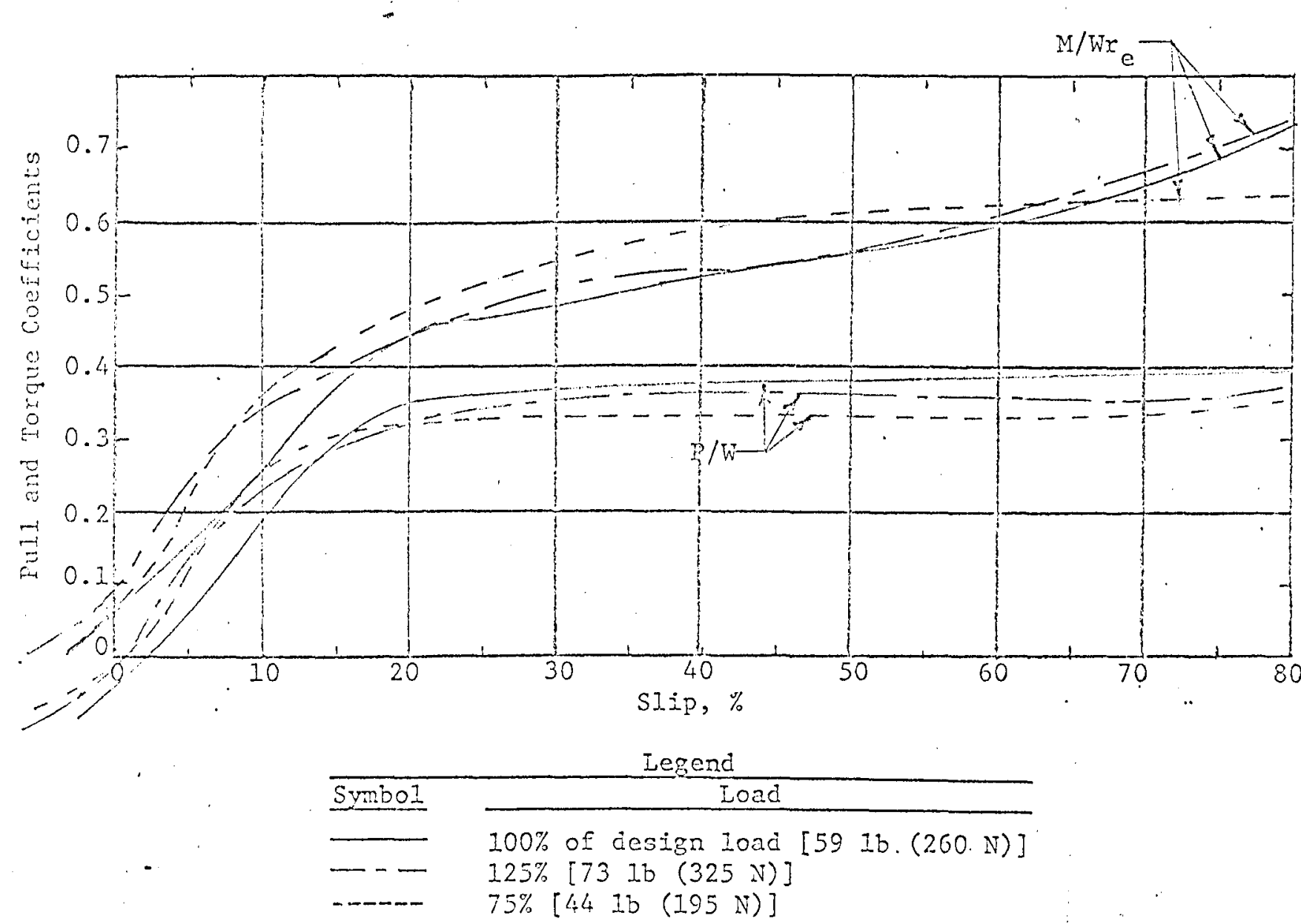

Fig. 16. Pull and torque coefficients versis s1.ip for the open-mesh wheel (GM VIII); air-dry sand $S_{1} ; G \approx 2.0$ psi/in.; $c=0.0$ psi: $w<0.5 \%$ 


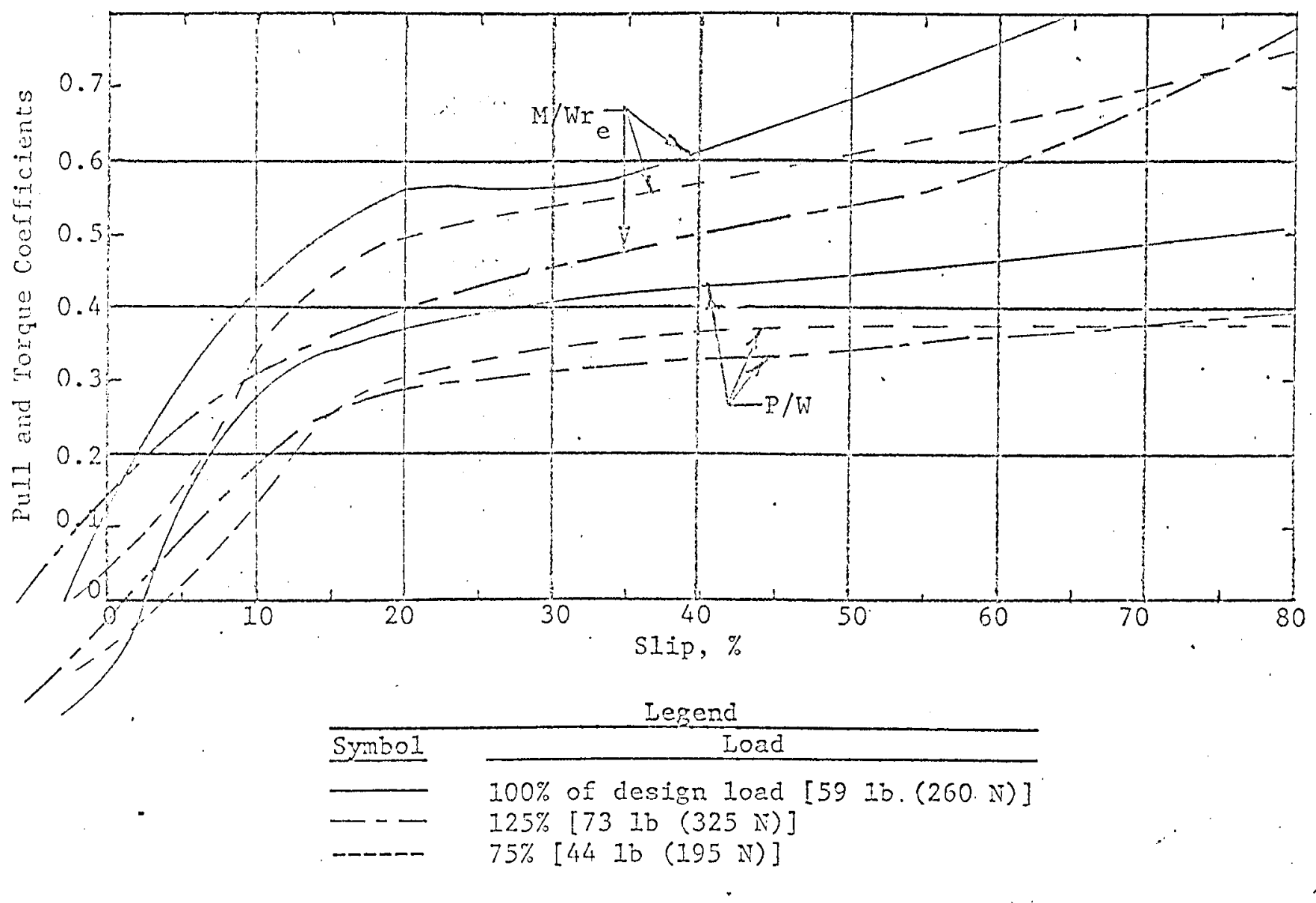

Fig. 17. Pull and torque coefficients versus slip for the open-mesh wheel (GM VIII); wet sand $C_{0} ; G=0.8$ psi/in.; $c=0.4$ psi; $w=1.4 \%$ 


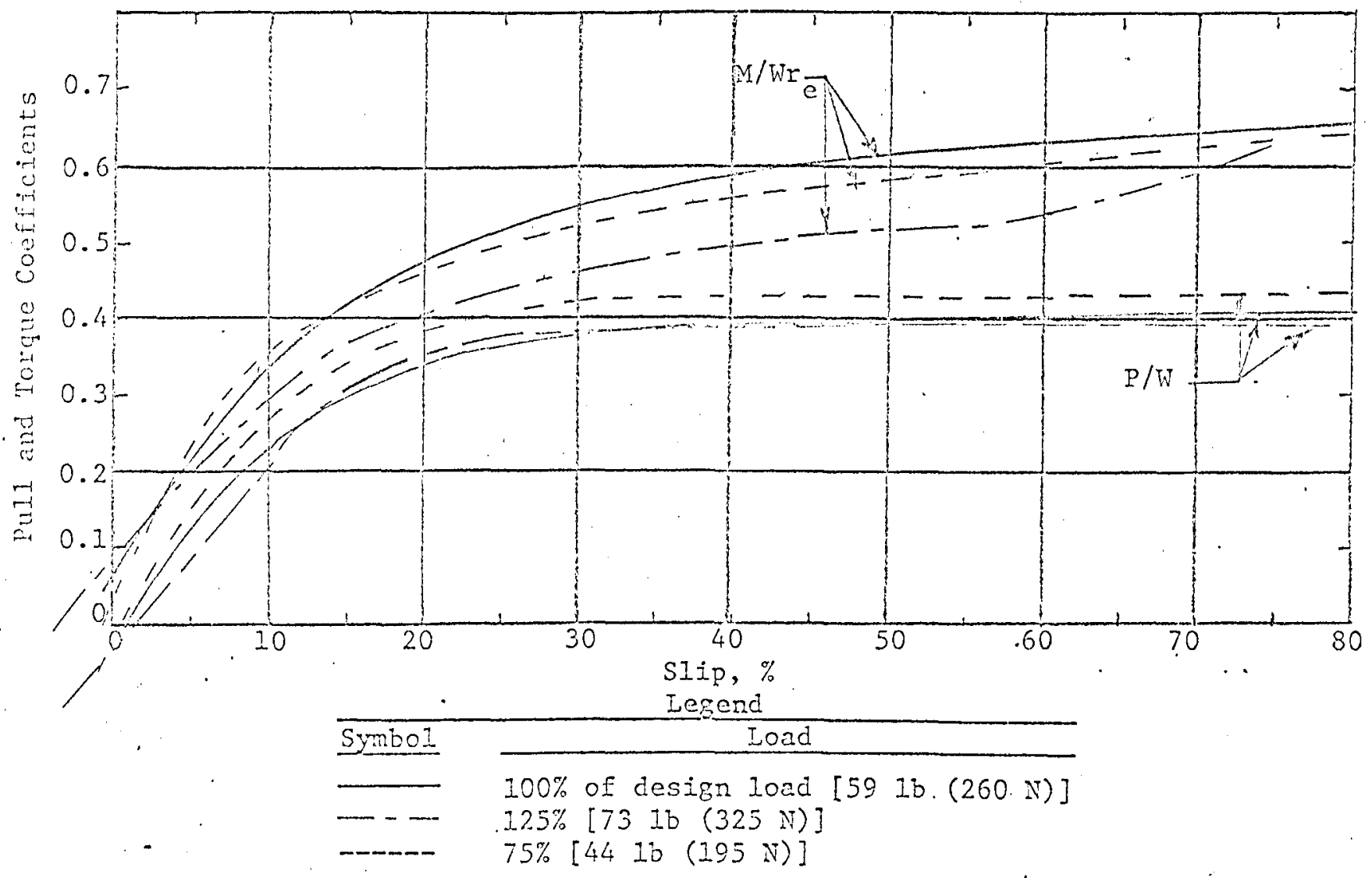

- Eig. 18. Pull and torque coefficients versus slip for the open-mesh wheel (GM VIII); wet sand $C_{1}^{\prime} ; G \approx 4.9$ psi/in.; $c=0.09 \mathrm{psi} ; w=1.4 \%$ 


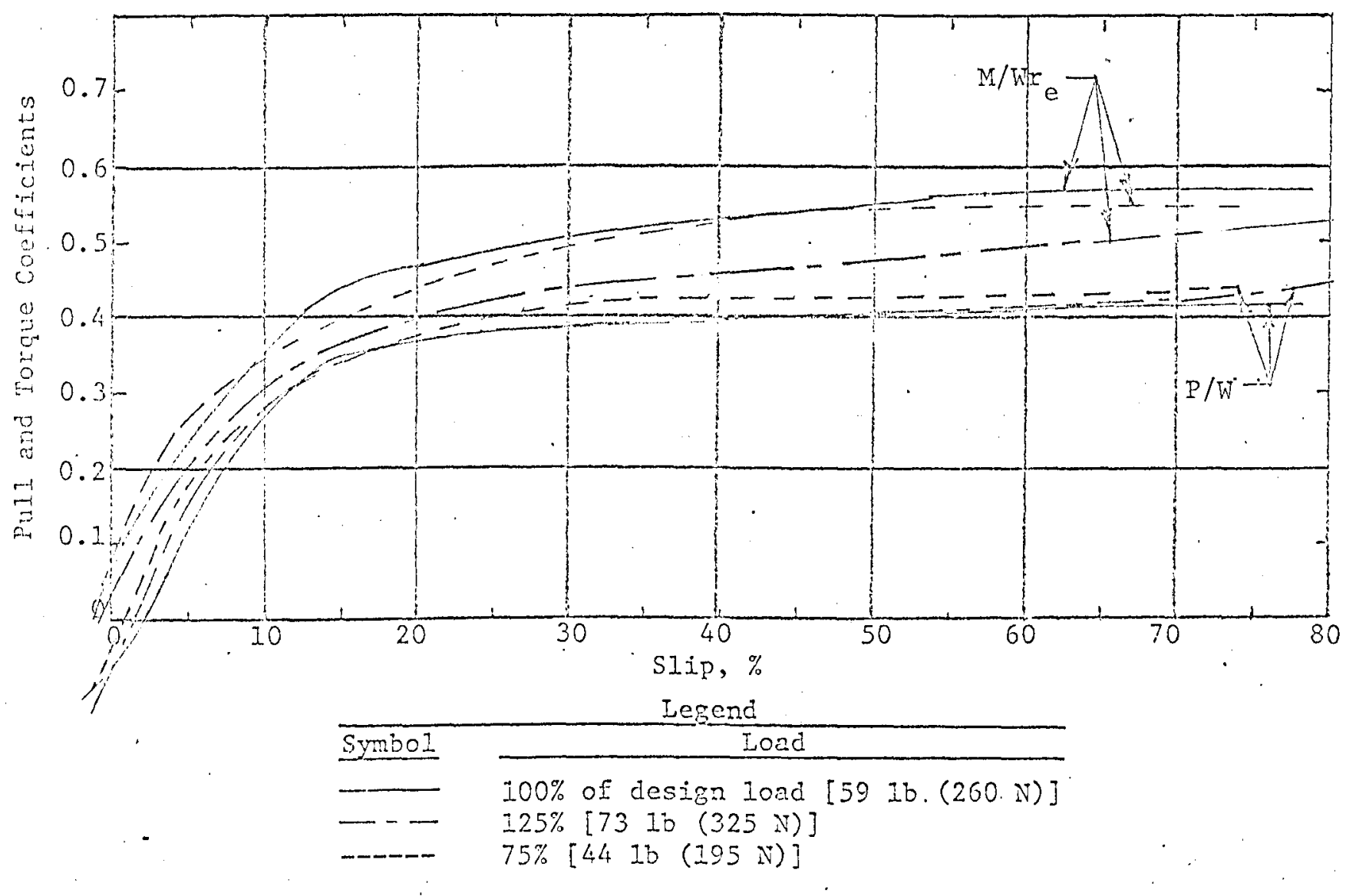

Fig. 19. Pull and torque coefficients yersus slip for the oden-mesh wheel (GM VIII); wet sand $\mathrm{C}_{2} ; G \approx 12.0$ psi/in.; $c=0.16$ psi; $w=1.4 \%$ 


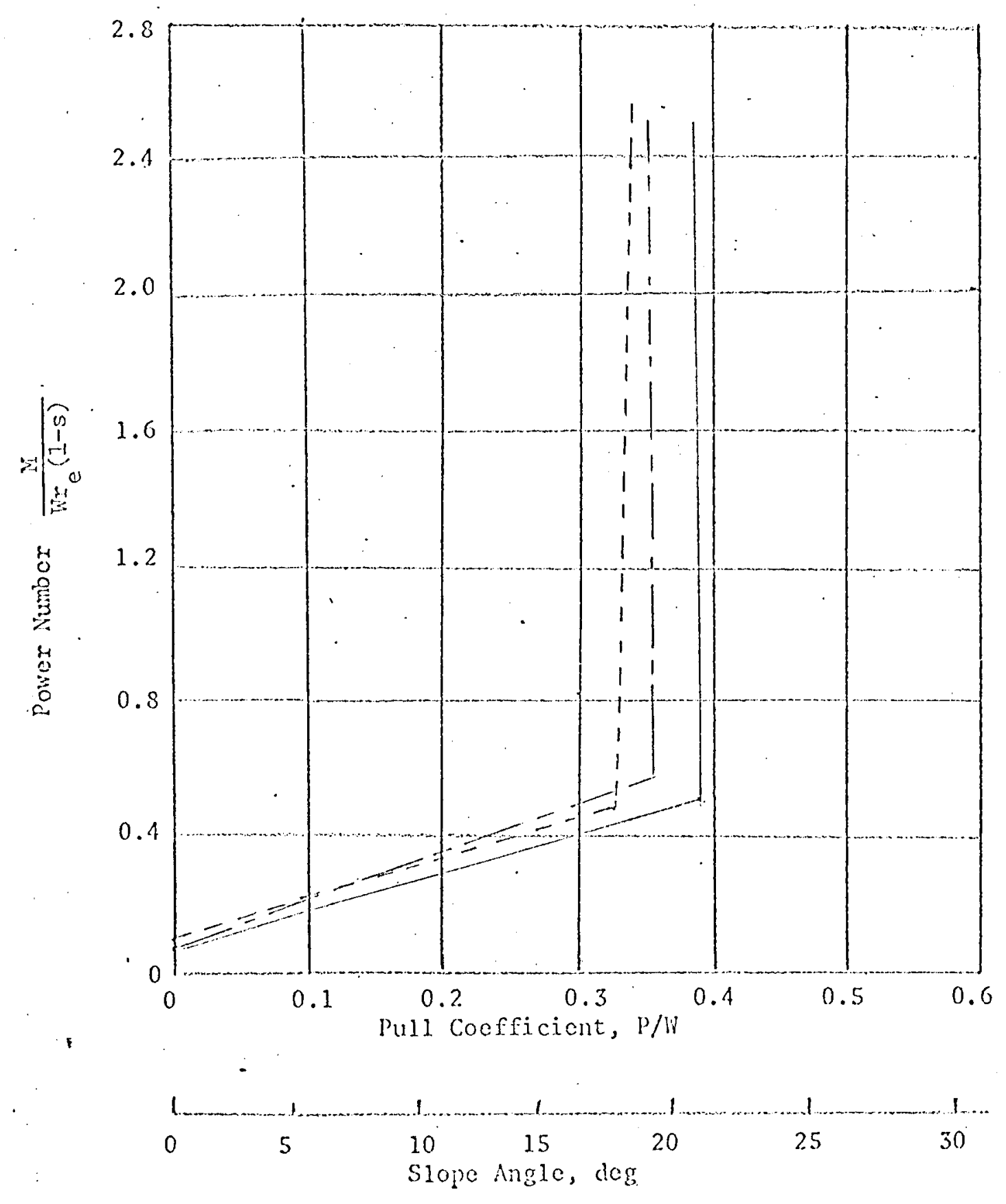

Legend

\begin{tabular}{|c|c|}
\hline Symbol & Loacl \\
\hline $\bar{\cdots}$ & $\begin{array}{l}100 \% \text { of design load }[59 \text { lb. }(250 \mathrm{~N})] \\
125 \%[73 \mathrm{lb}(325 \mathrm{~N})]\end{array}$ \\
\hline
\end{tabular}

Fig. 20. Power number versus pull coefficient for the open-mesh whed (GM VIII); air-dry sand $\mathrm{S}_{1} ; \mathrm{G} \% 2.0$ psi/in.; $c=0.0$ psi; $\mathrm{w}:=1.4 \%$ 

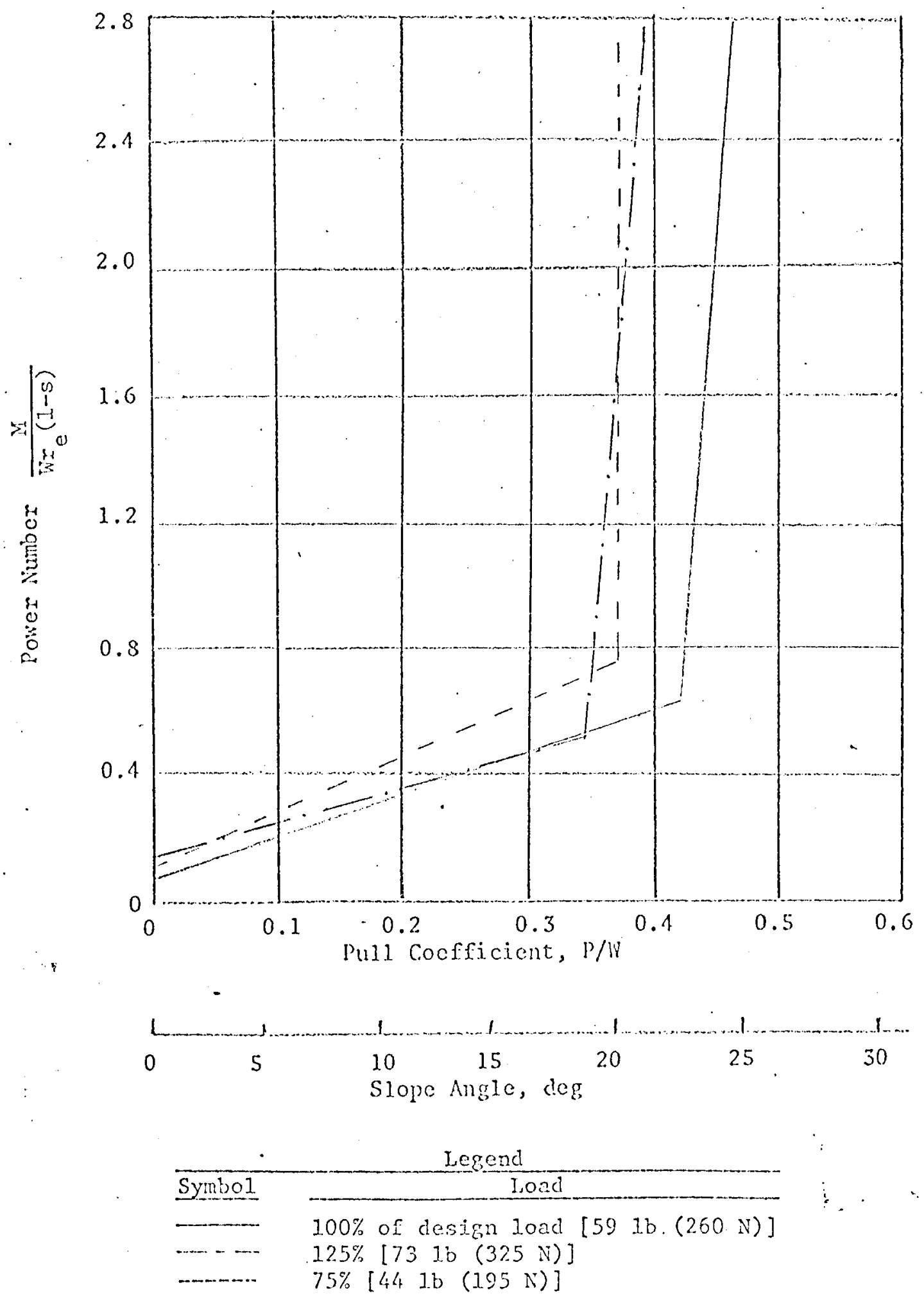

Fig. 21. Power number versus pull coefficient for the open`mesh wheci (GN VIII); vet sand $C_{0} ; G=0.8$ psi/in.; $c=0.0$ t psi; $w=1.4 \%$ 

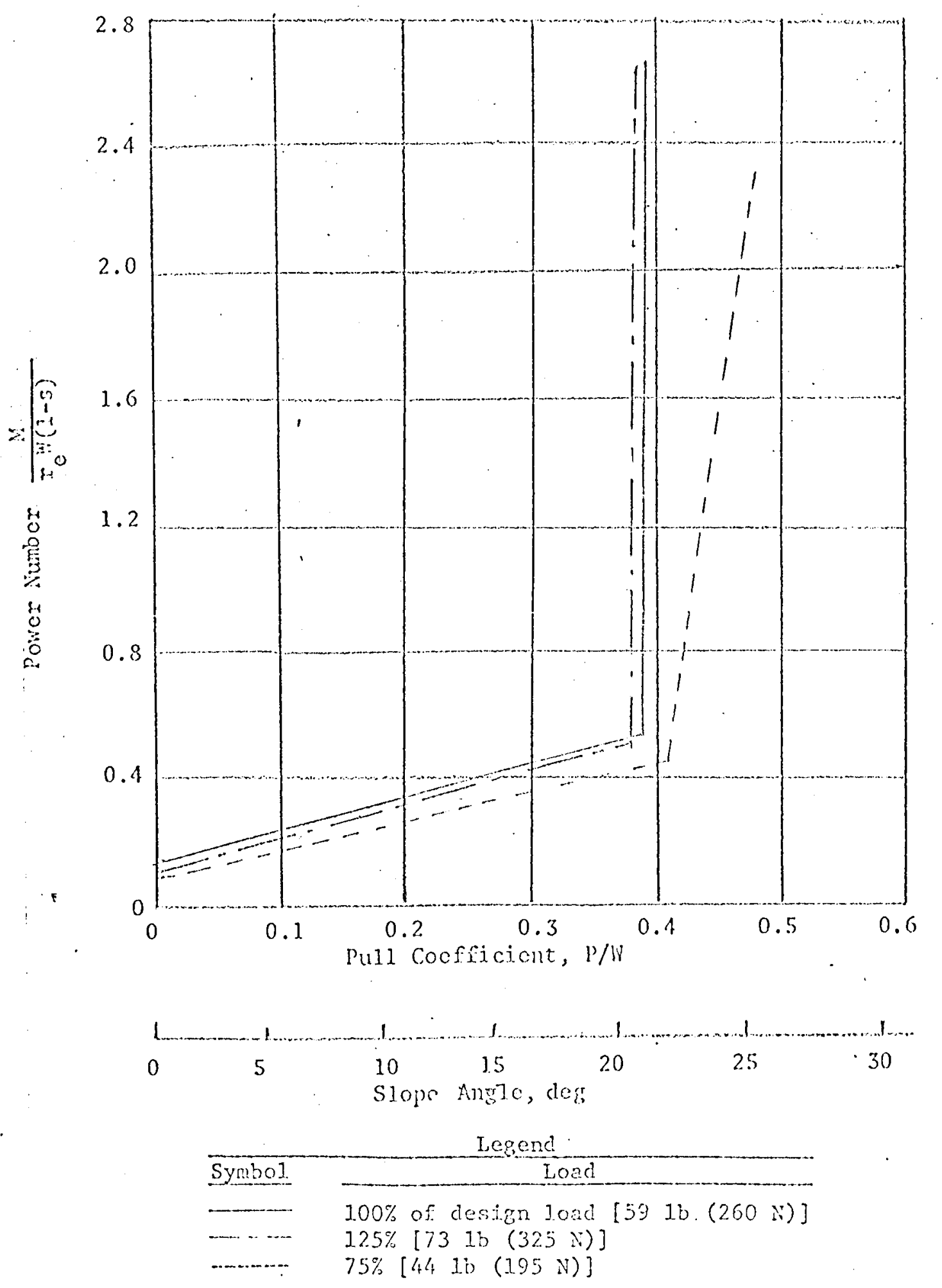

Fig. 2.2. Power number versus pull coefficient for the open-mosh wheel (GM VIIT); wet sand $C_{j}^{\prime} ; G \% 4.9$ psi/in.; $c=0.09$ psi; $w:=1.4 \%$ 

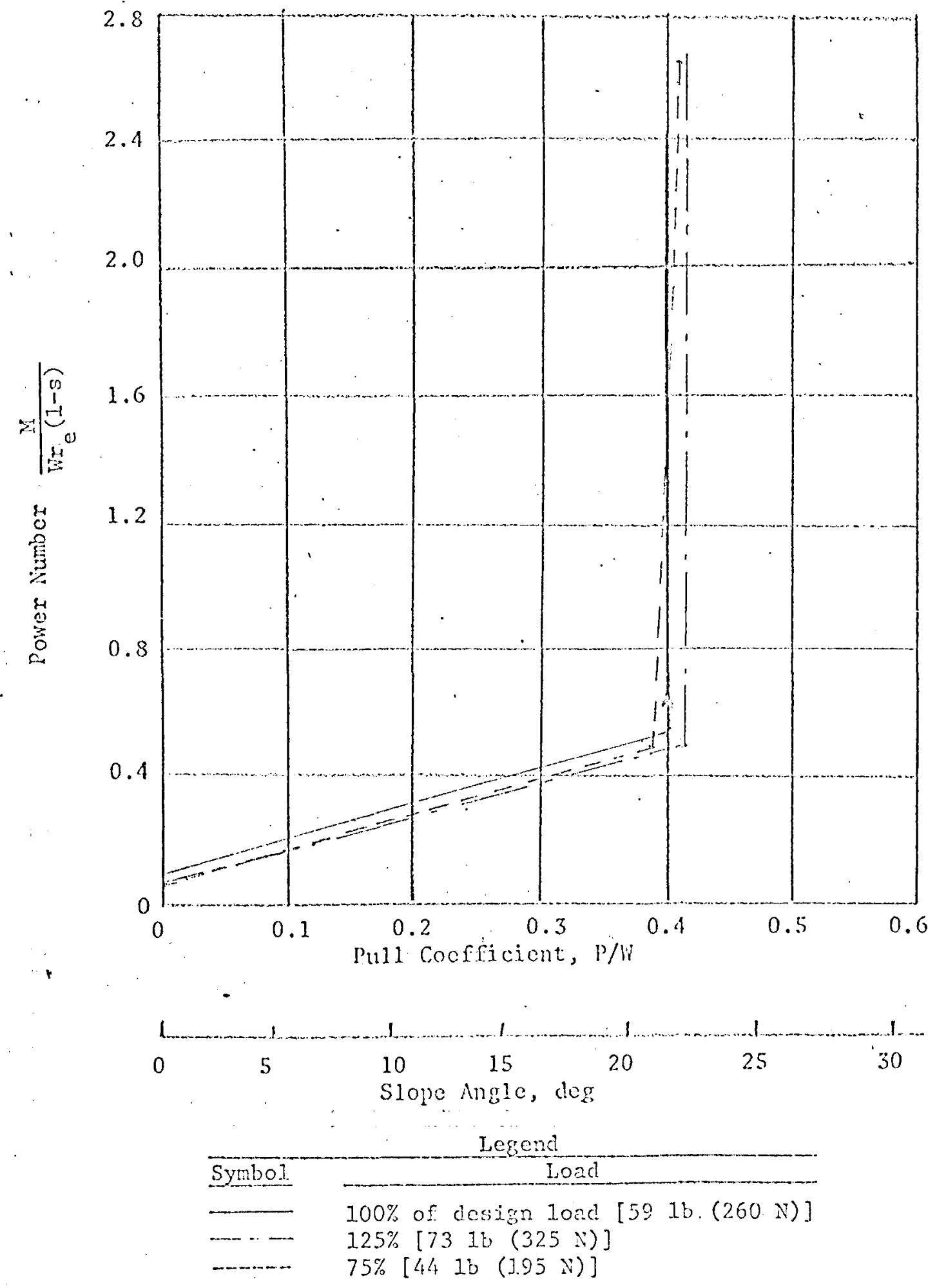

Fig. 23. power number versus pull coefficient for the ofen-tnesh wheel (Cr! VTII); wet sand $C_{2} ; G=12.0$ psi/in.; $c=0.16$ psi; $v=1.4 \%$ 


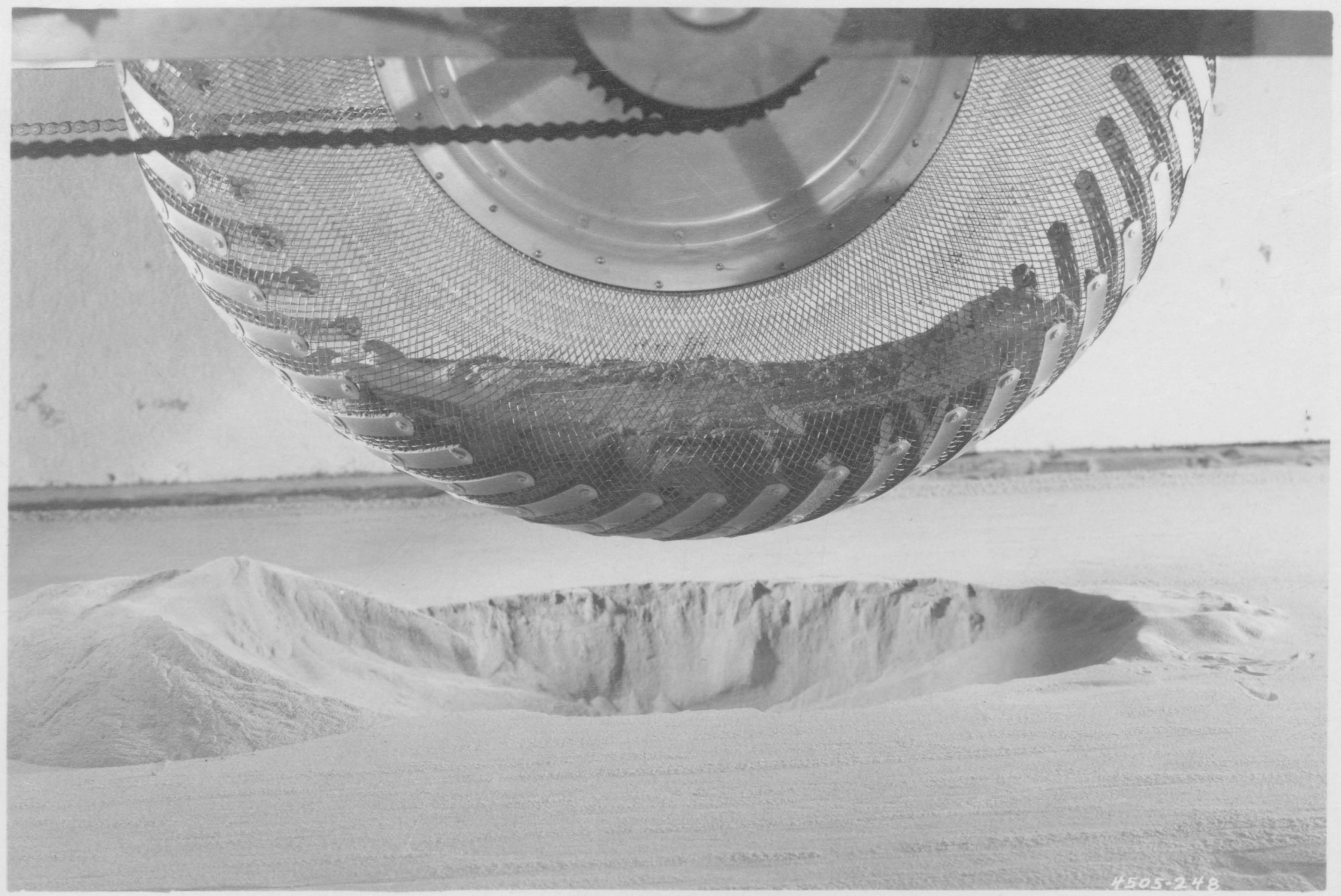

Fig. 24. Sand $[\approx 25 \mathrm{lb}(110 \mathrm{~N})]$ trapped in open-mesh wheel (accurnulation of sand begins at approximately $10 \% \mathrm{slip}$ ) 


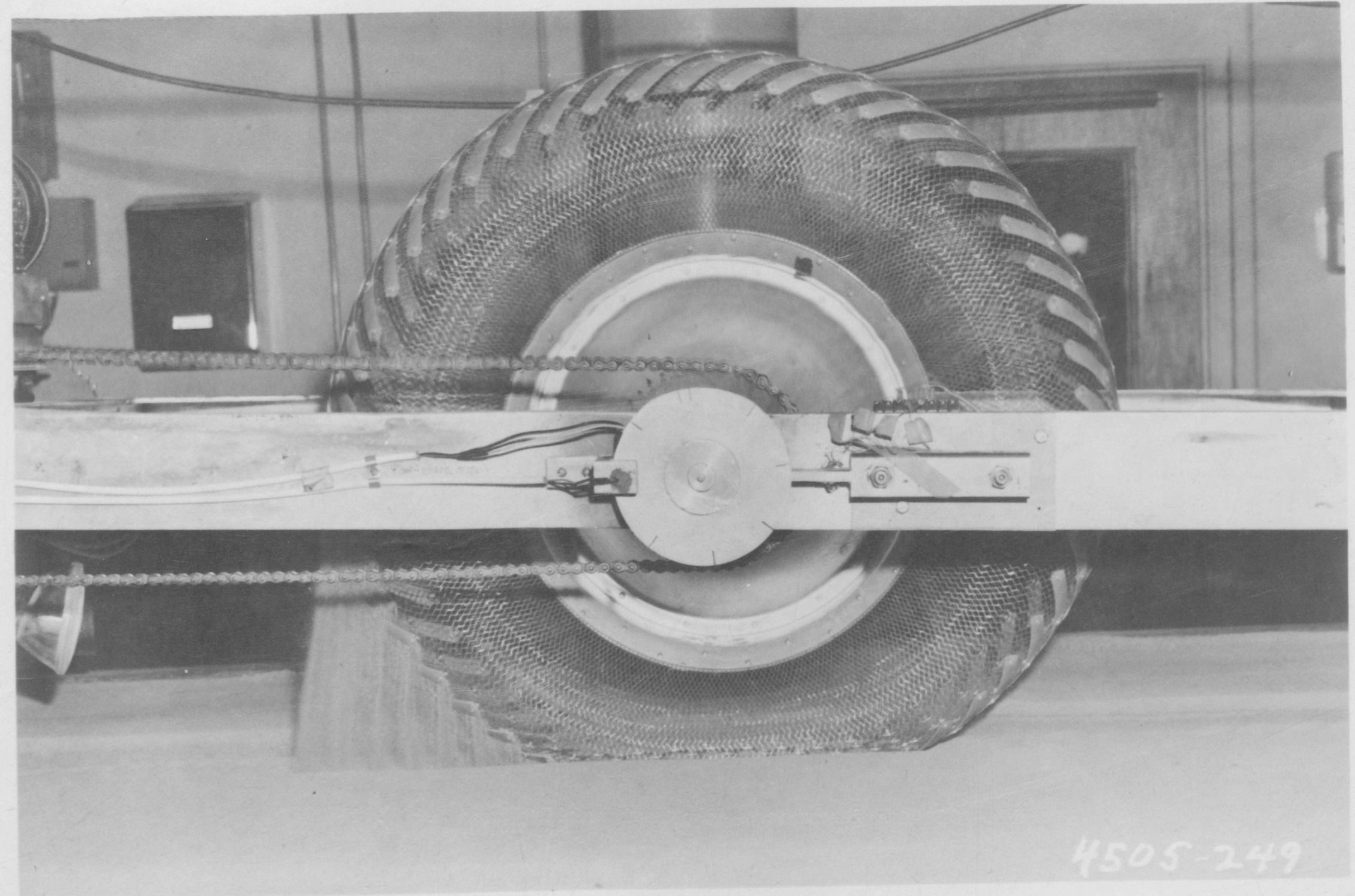

Fig. 25. Sand falling from open-mesh wheel at $\approx 10 \%$ slip 


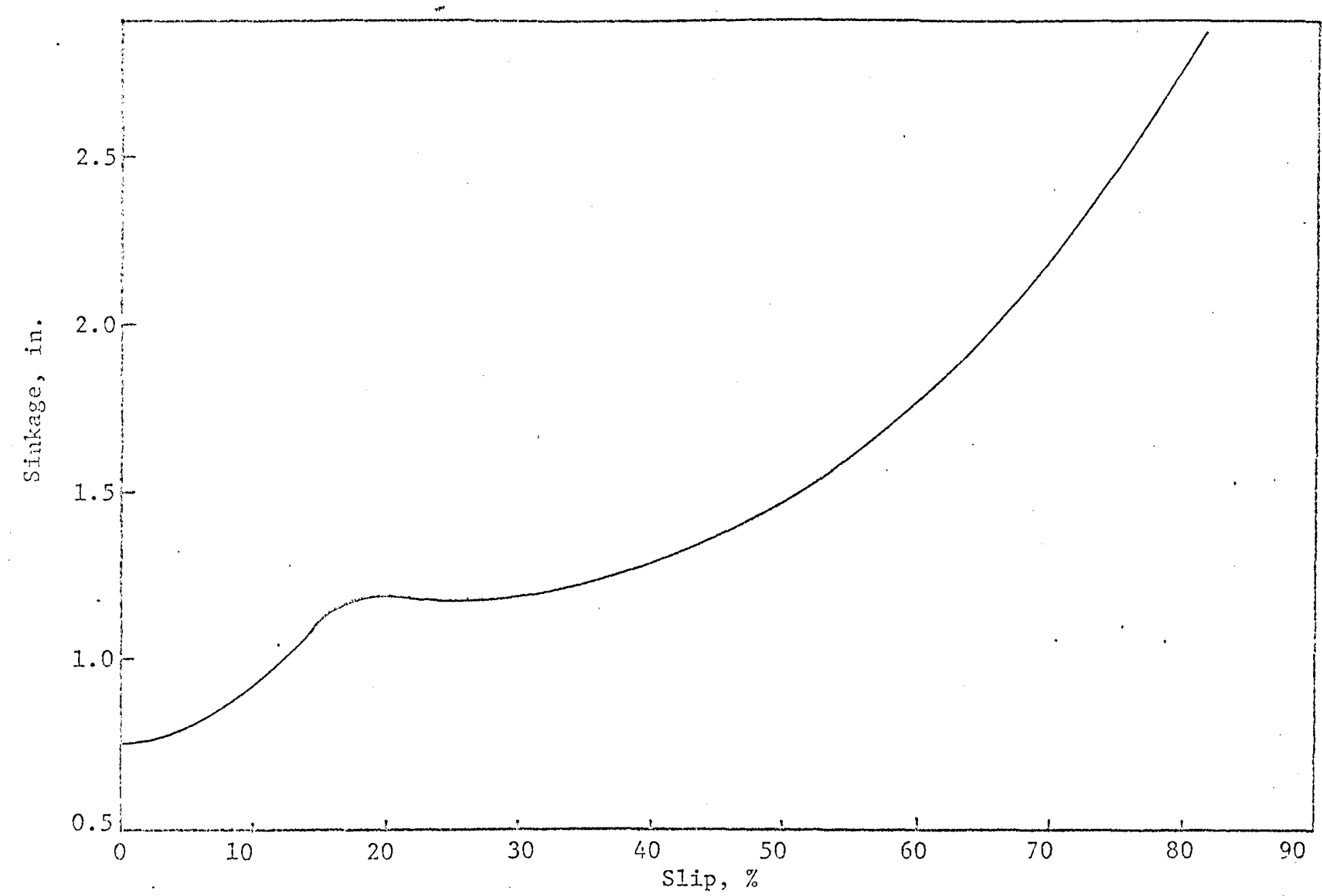

Fig. 26. Sinkage versus slip for the open-mesh wheel (GM VIII); wet sand $C_{0}: G \cdots 0.8$ psi $/$ in.; $c=0.4$ psi;

$\mathrm{w}=1.4 \% ; 10 \mathrm{ad}=591 \mathrm{~b}(260 \mathrm{~N})$ 


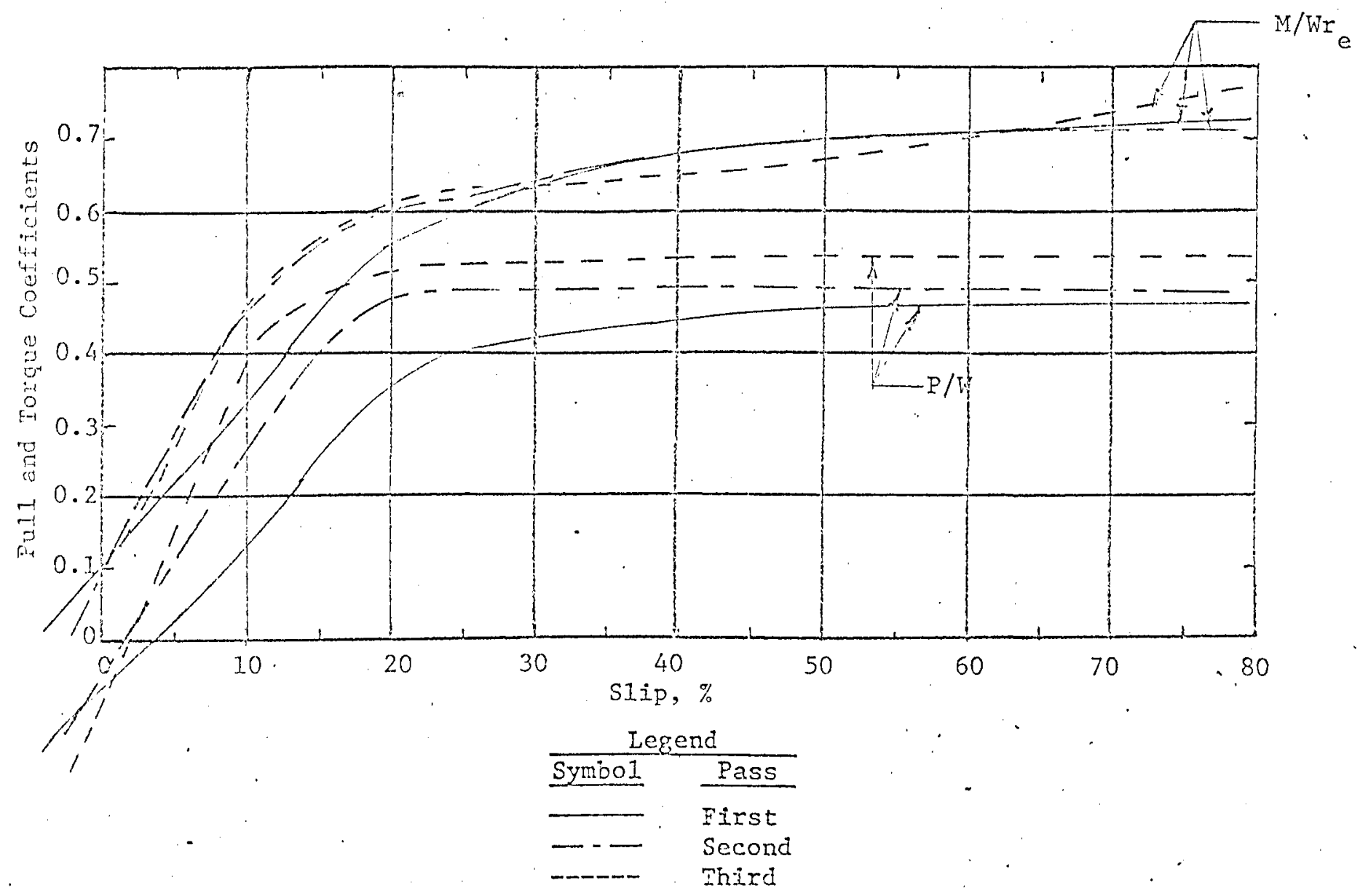

FIg. 27. Pull and torque coefficients versus slip forthe fabric-covered (GM VII); wet sand $C_{0}: G \cdot 0.8$ psi/in.; $c=0.04$ psi; $w=1.4 \%$;

load $=59 \mathrm{Ib} \cdot(260 \mathrm{~N})$ 


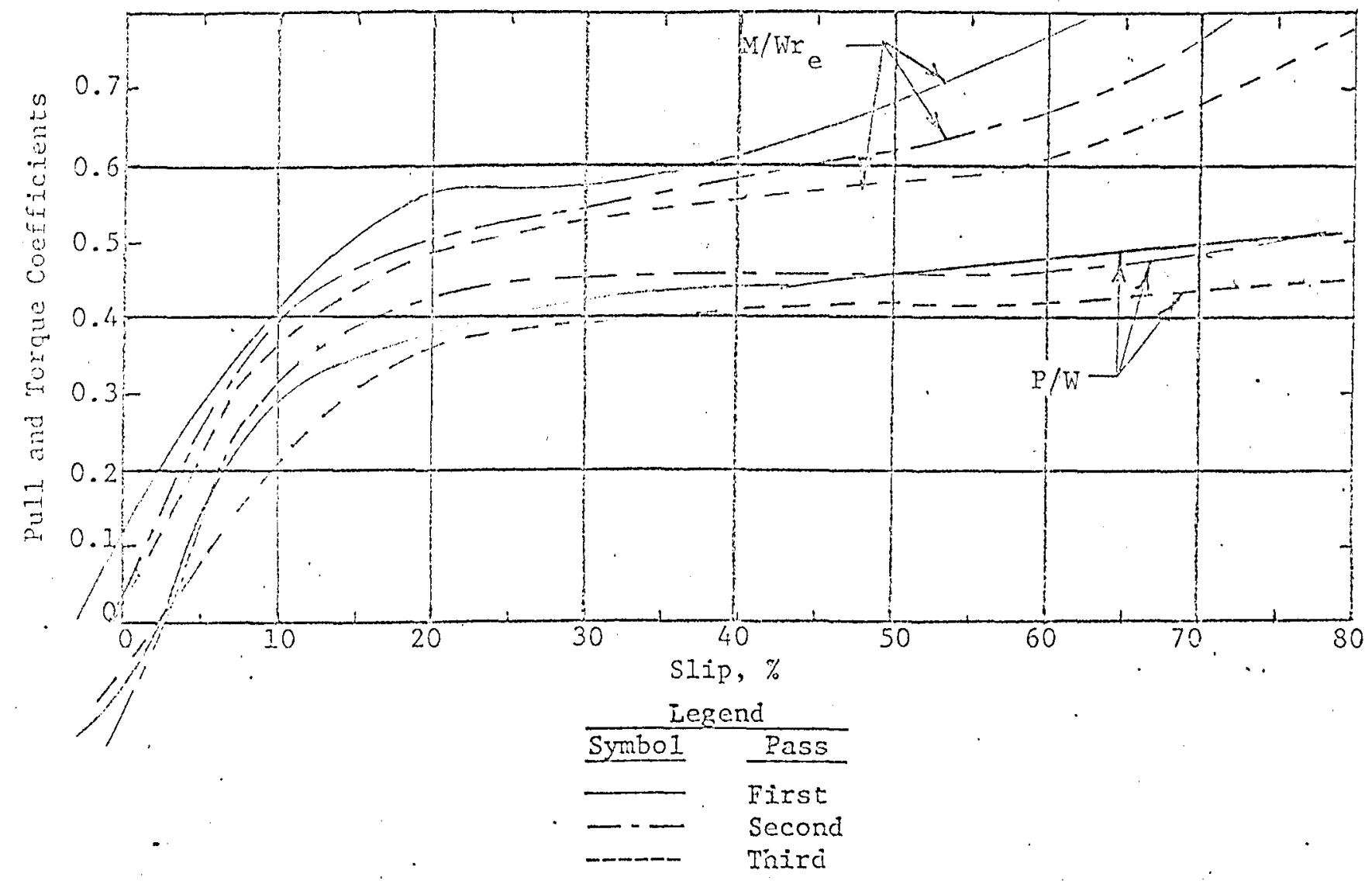

- Hig. 28. PuIl and torque coefficients versus slip for the open-mesh wheeI: (GM VIII) wet and $C_{0} ; G: 0.8$ psi/in.; $c=0.04$ psi; $w=1.4 \%$ load $=59 \mathrm{Ib}(260 \mathrm{~N})$ 
